Goodness and Limit: the Ethics of Eugenio Trias

\title{
Bondad y límite: la ética de Eugenio Trías
}

\author{
Juan Alberto Sucasas Peón
}

Universidade da Coruña (UDC) alberto.sucasas@udc.es

DOI: https://doi.org/10.15366/bp2019.22.001

Bajo Palabra. II Época. No 22. Pgs: 21-56

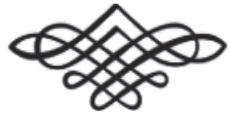


Recibido: 02/03/2019

Aprobado: 02/10/2019

\section{Resumen}

La filosofía del límite de Eugenio Trías propone una teoría ontológica donde se distinguen tres cercos (del aparecer, hermético y limítrofe) y cuatro barrios de la "ciudad fronteriza» (filosófico, religioso, estético y ético). Este texto explora el último de ellos. Analiza la ética como acontecimiento en el que intervienen tres clases de subjetividad: el sujeto 1 (emisor de la orden), el sujeto 2 (receptor) y el sujeto 3 (agente). Por otro lado, esa concepción ético-metafísica es remitida a una inspiración religiosa, la del Israel bíblico, y relacionada con la experiencia contemporánea de la barbarie.

Palabras clave: límite; ética; metafisica; judaísmo; barbarie.

\section{Abstract}

The philosophy of the limit of Eugenio Trías proposes an ontological theory where three areas [cercos] are distinguished (of the appearance, hermetic and bordering) and four neighborhoods of the border city (philosophical, religious, aesthetic and ethical). This text explores the last of them. It analyzes ethics as an event in which three classes of subjectivity intervene: subject 1 (issuer of the order), subject 2 (receiver) and subject 3 (agent). On the other hand, that ethical-metaphysical conception is remitted to a religious inspiration, that of biblical Israel, and related to the contemporary experience of barbarism.

Keywords: Limit; Ethics; Metaphysics; Judaism; barbarism. 
$\mathrm{T}$ odo pensamiento creador, para no desmerecer del viejo anhelo filosófico de esclarecer en el elemento del concepto la íntegra experiencia humana, ha de afrontar un exigente desafío, el de conciliar en síntesis armónica su concepción nuclear (el filosofema inspirador del despliegue categorial, la idea que singulariza a cada filósofo) y el respeto a la irreductible diversidad inherente a aquella experiencia, de suerte tal que en el propio trabajo filosófico, en la reflexión y en la escritura a ella asociada, se abre paso el dilema ontológico Unidad/Diversidad, la antinomia entre lo Uno y lo Múltiple. Traicionaría la vocación de incondicional fidelidad a lo real el pensador que, por amor a $s u$ idea, estuviese dispuesto a preterir la intrínseca pluralidad exhibida por el ser en sus variados modos de manifestarse y afectarnos, como si correspondiese al mundo plegarse al artificio del concepto en lugar de proponerse este la plena elucidación de aquel. ( $\mathrm{Si}$ es razonable mantener en el término idealismo una acepción peyorativa, lo justificaría, por encima de cualquier otra consideración, esa voluntad usurpadora, dispuesta a sacrificar la pluralidad dada a un fetiche lógico. Cómplice de una violencia superpuesta a la intelección, la empresa filosófica se desvirtúa entonces, ahogado el designio de entender por la pulsión de dominar). Pero no sería menos infiel a la exigencia filosófica quien, en nombre de los imprescriptibles derechos de la Pluralidad, renunciase a dar razón de esta según la disciplina del concepto. No hay fórmula o regla que resuelva de antemano esa aguda tensión; es competencia del genio de cada filósofo encontrar la figura especulativa capaz de dar satisfacción a uno y otro requerimientos, ambos legítimos.

Buen ejemplo de ello es el sostenido esfuerzo con que, a lo largo de casi tres décadas (entre 1985, con la publicación de Los límites del mundo, y 2013, año de su fallecimiento), Eugenio Trías ha ido construyendo una filosofía del limite, escrupulosamente leal al doble imperativo: conferir pleno desarrollo conceptual a una intuición ontológica (la idea de límite, en fecunda pero tensa relación con el principio de variación $)^{1}$ y someter su potencial filosófico al reto de una experiencia marcada por

\footnotetext{
${ }_{1}$ Una consideración retrospectiva del corpus pone de manifiesto cómo la noción de límite pronto se convirtió en principio rector de toda la aventura; sin llegar a anular el principio de variación, sí lo postergó a un discreto segundo plano. Hegemonía cuestionada por El hilo de la verdad (Barcelona, Destino, 2004), que reivindica una importancia pareja para los dos filosofemas. Ese texto ocupa un lugar crucial: tardío en su datación, confluye en él un trabajo categorial de veinte años, susceptible ahora de comparecer en una gran síntesis final; lo singulariza, además, el empeño de hallar un punto de equilibrio, tanto entre ideas (aunque quizá fuese más aconsejable hablar de dos matrices de inspiración filosófica, una de naturaleza topológica —límite - y otra de índole temporal
} 
la diversidad. Las dos tareas han avanzado parejas. El autor de Ciudad sobre ciudad (2001) ha ido diseñando y construyendo, según la metafórica operante en esa obra, una ciudad del límite; los grandes hitos del proyecto son, aparte de los libros ya citados, La aventura filosófica (1988), Lógica del limite (1991), La edad del espíritu (1994) y La razón fronteriza (1999). A lo largo de esa serie, el pensamiento de Trías no discurre linealmente, sino más bien en círculo o espiral: cada nuevo texto retoma, para ahondarlo y recrearlo, lo ya alcanzado por los precedentes, con la intención de penetrar con creciente rigor en un territorio del que había tomado posesión la obra inaugural (Los limites del mundo) pero que solo al término del recorrido (sería el honor de El hilo de la verdad haber vencido al Minotauro y estar en condiciones de ofrecer una salida del laberinto filosófico) puede considerarse definitivamente cartografiado.

Por un lado, heredero de una tradición que elevó la «ciencia del ser en tanto que ser» a la dignidad de philosophia proté, Trías hace que toda su empresa pivote sobre una indagación ontológica de nuevo cuño (por más que reconozca, y reivindique, su raigambre platónica) en la que confluyen una ontología en sentido estricto (doctrina de los tres cercos y tabla categorial de siete elementos) y, más allá de ella, en el orden último de fundamentación, una exploración topológica del Limite como instancia absolutamente fundante, de cuyo dinamismo interno provienen los tres cercos. En ese programa se materializa el gesto especulativo de Trías, su aportación más genuinamente filosófica. Pero el trazado de la trinidad de cercos y su coronación topológica en el espacio-luz no agotan esa aventura de pensamiento. De ella forma parte, asimismo, la firme decisión de atravesar, orientada por la brújula del principio ontológico-topológico, todo el espacio urbano de la ciudad limitrofe, desde una actitud respetuosa para con la fisonomía o configuración de cada uno de sus barrios (es decir, de los grandes ámbitos, interconectados pero de suyo diversos, de la experiencia humana). Trías distingue cuatro: filosófico (cuyo perfil bosquejaron las consideraciones anteriores: sus dos grandes sectores son ontología y teoría del conocimiento, nucleada esta en torno a la noción de verdad propia de una razón fronteriza), religioso, estético y ético-práctico. Como urbanista, Trías no ha prestado la misma atención a los cuatro distritos. Al menos eso parece sugerir la desigual extensión con que los ha abordado. Tres de ellos han sido objeto de análisis minucioso: es el caso, por supuesto, del quartier filosófico, omnipresente en todo el corpus, pero también del religioso (a visitar el "casco antiguo» de la urbe limítrofe se consagró la colosal obra de 1994, La edad del espiritu, generosamente acompañada de tres hermanas menores —Diccionario del Espiritu, Pensar la religión y Por qué necesita-

- principio de variación -) como entre modalidades de escritura (El hilo de la verdad acoge por igual capítulos sistemáticos y variaciones ensayísticas, unificando así los dos grandes ciclos de la producción filosófica de Trías). 
mos la religión —, publicadas, respectivamente, en 1996, 1997 y 2000) y el estético (ampliamente teorizado en Los límites del mundo, Lógica del límite y Ciudad sobre ciudad, para no decir nada del tratamiento de la manzana musical — con mayor precisión, la evolución musical de la Europa moderna- en El canto de las sirenas, de 2007, y La imaginación sonora, de 2010; póstumamente, en 2013, se publicaría un ensayo sobre cine, De cine. Aventuras y extravios). No ha merecido el barrio ético (en realidad, ético-político, por más que la aproximación a lo político presuponga, en la economía interna de la filosofía del límite, una previa fundación del orbe ético) desvelo semejante: tan solo dos textos sucintos, aparte de los capítulos que merece en las obras de síntesis, le están dedicados, Ética y condición humana (2000) y La política y su sombra (2005). Pero el criterio cuantitativo puede resultar engañoso, muy en particular en relación al primero de ellos, el que aquí demanda nuestra máxima atención. A pesar de su brevedad, Ética y condición humana, libro indisociable de la constante reelaboración del hecho moral en las obras mayores, explora un campo temático decisivo para la filosofía limítrofe. No se trata de un barrio marginal, desplazado a la periferia o extrarradio, que cupiese desdeñar en el recorrido de la ciudad del límite. Muy al contrario, lo ético ocupa en el interés de Trías un lugar crucial, sin el cual se resentiría el sentido global de su proyecto filosófico. ${ }^{2}$

Demostrarlo será el objetivo esencial de estas páginas. El itinerario abarca tres etapas: exposición sintética de la ontología de los tres cercos, imprescindible para enmarcar el ámbito ético; desarrollo de este en una fenomenología, no ajena a exigencias metafísicas, de la conciencia moral, en cuyo curso se da cuenta de los conceptos centrales de la ética (imperativo; culpa; libertad; responsabilidad; bien y mal...); dos reflexiones finales, de carácter menos expositivo que crítico (en diálogo con el autor de la filosofía del límite), acerca del trasfondo de esa fenomenología y de la relevancia de su presentación del nexo libertad-mal en orden a iluminar el claroscuro de nuestro presente.

\section{Una ontología trágica}

LA ONTOLOGÍA NO APORTA, POR sí sOLA, la sustancia ética, pero sí suministra el marco de su despliegue: si lo ético es acontecimiento, lo ontológico constituye su escenario. Trías propone distinguir tres cercos o ámbitos (que no mundos; la de mun-

\footnotetext{
2 Aunque la razón fronteriza tenga su organon en la gnoseología (determinación de la noción de verdad), pone el conocimiento al servicio de la transformación de la existencia, pues la mueve el empeño de «contribuir al alzado de esta a aquella condición en la cual se puede alcanzar una vida mejor. Eso significa que la razón fronteriza tiene una orientación práctica que le es característica» (La razón fronteriza, Barcelona, Destino, 1999, pp. 349-350).
} 
do es noción solo aplicable al primero de ellos). En primer término, el cerco del aparecer: en su interior tiene lugar la totalidad de fenómenos o sucesos materiales que configuran nuestro mundo; los define, esencialmente, su accesibilidad a la experiencia del sujeto. Pero al espacio de lo que se muestra o hace manifiesto (el fenómeno) ha de añadirse el de lo replegado en el misterio o reacio a mostración; ese ámbito, nouménico o meta-físico, recibe el nombre de cerco hermético. Entre esos dos cercos se dibuja, a manera de franja intersticial o línea fronteriza, un tercero, el cerco limitrofe, lugar del límite o frontera, que, en polémica con el enfoque negativista hegemónico en la filosofía moderna (límite como "semáforo en rojo» epistemológico, que invita a ceńirse a lo dado y, por ende, cognoscible), cobra un protagonismo esencial, tanto ontológico (el tercer cerco define, implícitamente, los otros dos: cerco del aparecer es, a fin de cuentas, aquello que comparece aquende el límite, mientras que cerco hermético es lo que mora, en irresoluble enigma, allende el límite; la tradición metafísica, comprometida con un a priori ontológico dualista, no tomó conciencia de que más acá y más allá presuponen un espacio liminar que permita diferenciar ambos lados) como antropológico (no en vano el hombre es, por antonomasia, el fronterizo). ${ }^{3}$ Pero el límite no solo ostenta la dignidad -ontológica: Trías califica la tríada de cercos de ontología trágica, por cuanto da cuenta de un ser escindido en una pluralidad de ámbitos y remitido a un fundamento en falta- de ser el cerco decisivo; más allá de ello, le corresponde un privilegio que, en contraposición a lo meramente ontológico, ha de denominarse topológico: el Limite es, como espacio-luz, instancia última de fundamentación, respecto a la cual el ser mismo resulta algo fundado (del dinamismo interno del Límite, concebido por Trías como unidad que se desdobla en lo Mismo y lo Otro, brotan los tres cercos; estos no son, a la postre, sino proyecciones suyas). De ese modo, la indagación ontológica — ser del límite cartografiado en la trinidad de cercos-culmina en una visión topológica — del Limite como Absoluto fundante-

Para la presentación de la ética limítrofe, al igual que para cualquiera de los otros tres barrios fronterizos, ${ }^{4}$ resulta imprescindible el recurso a la tabla categorial, de siete unidades, con que se nos propone pensar el ser dado en la triplicidad de cercos. Trías agrupa esas siete categorías en tres bloques, en estricta correspondencia con la trinidad ontológica. En primer lugar, cuatro categorías fenomenológicas, referidas al

«El Límite tiene, en relación a la condición humana, una doble significación que debe ser destacada. (...) El hombre es el gozne que articula y diferencia la naturaleza del mundo. Pero es también la bisagra que articula y diferencia al Mundo de lo que lo rebasa (en forma de misterio o de arcano). Es cópula y disyunción en un doble sentido: entre naturaleza y mundo, y entre este (como cerco de cuanto aparece) y el cerco hermético que constituye el punto de fuga del ser y del sentido» (Ética y condición humana, Barcelona, Península, 2000, p. 63).

4 Trías insiste en que los cuatro comparten idénticas determinaciones categoriales, si bien - lo establecimos desde el comienzo: al filósofo corresponde tanto poner en pie una visión unitaria del Todo como describir, respetando 
cerco del aparecer: matriz, el "fundamento en radical ausentación», 5 es decir, la naturaleza como sustrato materno o matricial del que proviene el mundo, pero que, a diferencia de este, no accede a desvelarse como presencia fenoménica (origen velado o ausencia del fundamento que confieren al cerco del aparecer consistencia trágica); existencia como dato inicial de la realidad mundana, desde el que cabe inferir, de un modo irreductiblemente conjetural, la matriz que la antecede (en ese sentido, el ordo essendi, donde la matriz ocupa el primer lugar de la serie categorial, difiere del ordo cognoscendi, pues lo primordial pre-mundano solo puede ser atisbado desde el dato primitivo de la existencia); la de limes es la tercera categoría fenoménica, cuyo rendimiento estriba en dar cuenta de la promoción del ser humano, originariamente remitido al cerco del aparecer como existente intramundano, a su verdadera condición, la humana conditio propia de quien habita el límite o frontera; por último, el lógos registra la metamorfosis experimentada por el mundo al poblarse de significaciones que el fronterizo introduce en él, de tal suerte que lo meramente físico adquiere un suplemento de inteligibilidad. Conforma el segundo tramo categorial la pareja de categorías hermenéuticas, cuyo referente es el cerco hermético: por un lado, la razón fronteriza instituye las claves interpretativas a las que ha de confiarse el acceso, nunca culminado en razón de su inherente alergia a hacerse patente, a lo hermético, lo afincado más allá del límite; por otro, el simbolo, categoría mística del encuentro entre el sujeto fronterizo y un núcleo de misterio que desafía, y frustra, toda tentativa de elucidación. Clausura la serie la categoría fronteriza, propia del cerco limítrofe, del ser del límite; en ella confluye y alcanza pleno cumplimiento (aunque solo a nivel ontológico; la inteligibilidad última es competencia de la reflexión topológica) el recorrido de las seis precedentes.

De las siete categorías la decisiva es, desde una perspectiva ética, la tercera, pues en ella asistimos al nacimiento mismo del sujeto como conciencia moral, en función de una llamada que, proveniente del otro lado del límite, obliga al existente humano, hasta entonces huésped del cerco del aparecer, a alzarse hasta el límite: ${ }^{6}$

Yo mismo avanzo hasta el límite del mundo y me planto en la frontera del sentido. Allende está lo que me excede, el otro mundo. El cual presiona sobre mí y sobre mi mundo

su respectiva heterogeneidad, sus diversas regiones - «siempre moduladas según la especificidad de cada uno de esos cuatro ámbitos» (Ciudad sobre ciudad, Barcelona, Destino, 2001, p. 38).

La razón fronteriza, op. cit., p. 131.

${ }^{6}$ Para el tratamiento de la ética en la filosofía del límite, cf. Los límites del mundo, Barcelona, Ariel, 1985, pp. 4684 («El acceso»); La aventura filosófica, Madrid, Mondadori, 1988, pp. 59-93 («La frase imperativa»); Lógica del limite, Barcelona, Destino, 1991, pp. $447-466$ («Pasión y logos»); La razón fronteriza, op. cit., pp. 65-75 («Ética fronteriza»); Ciudad sobre ciudad, op. cit., pp. 217-266 ("Ética y condición humana»); Etica y condición humana, op. cit., passim. Aun siendo su formulación primeriza, el diseño del ámbito ético en Los límites del mundo se mantiene, en lo esencial, a lo largo de cuatro lustros de insistente tematización del hecho moral: «La reflexión ética 
bajo el modo de un suplemento de interrogantes y de decisiones lingüísticas, pronunciadas desde el límite, mediante las cuales se capta, difícilmente, lo que "cerca está", el enigma. Un hiato gnoseológico sobreviene a la exploración que emprendo. Solo un salto hace posible salvar el bache crítico y proseguir el recorrido experiencial hasta que se libere una nueva senda, una segunda etapa del método. En ese salto se podrá instituir una segunda expansión de la razón, del lógos: la forma lingüística que determina el recorrido empírico de lo ético. ${ }^{7}$

Antes de adentrarnos en el nuevo territorio que la ética inaugura conviene insistir en que su tratamiento a cargo de Trías obedece al doble imperativo enunciado al comienzo: inserta lo ético en una propuesta filosófica centrada en una sola idea, la de límite (de hecho, será la dinámica entre los tres cercos — acuñando el término, nuestro filósofo retiene la noción militar de «asedio», y no solo la de cerca o vallado delimitadores de un territorio, pues le interesa destacar que los cercos ejercen presión unos sobre otros - la convocada a iluminar el orbe ético), pero a la par mantiene un escrupuloso respeto a su especificidad, asumiendo el designio kantiano de mantener innegociable la irreductibilidad de lo ético a cualquier facticidad:

Valor y creencia no pueden derivarse de lo que puede ser representado y conocido. Ciencia y lenguaje "representativo" no pueden jamás fundar evaluación ni estimativa ni pueden motivar un ápice la voluntad, dar objeto alguno a ese querer. Valor y voluntad tienen su fundamento, su estímulo y su motivo más allá de los límites del mundo que podemos representarnos. Sus móviles son metafísicos. ${ }^{8}$

\section{Ética fronteriza}

Todo comienza con una llamada. Su destinatario es el sujeto humano, hasta ese instante inmerso en el entorno natural pero sacudido ahora de su sopor animal por una voz de origen misterioso y forma imperativa. No cabe asimilarla a ninguno de los ruidos o sonoridades habituales en el medio físico; evidencia, muy al contrario, una radical exterioridad. De hecho, su audición obliga al receptor a alzarse en dirección al lugar de donde la voz proviene. (Antropogénesis en versión limítrofe: si la humanización acontece cuando el homínido adopta la postura erguida — homo erectus — y accede al lenguaje — homo loquens—, la escena ética primitiva supone

que llevé a cabo en Los límites del mundo es, sin duda, la pieza clave de una ética fronteriza» (La razón fronteriza, op. cit., p. 67).

7 Los limites del mundo, op. cit., p. 43.

${ }^{8}$ Los límites del mundo, op. cit., p. 79. "Lo que se descubre en filosofía, con Kant, es la flexibilidad de la razón, del lógos (...). La razón es flexible y tiene sobre todo dos flexiones, la indicativa y la imperativa. (...) En el gozne entre ambas flexiones se constituye el espacio crítico de la filosofía. Ese espacio crítico mantiene firme la infinita distancia entre ser y deber sern (La aventura filosófica, op. cit., p. 307). 
un alzado y una escucha. Ethica ex auditu). Se produce, así, una interlocución asimétrica en la que Alguien habla a otro sujeto, el humano, sometido a una audición silenciosa:

Lo peculiar de esa frase es que el sujeto que la enuncia, el yo del "yo te ordeno que..." debe diferenciarse radicalmente de aquel sujeto ( yo mismo, si quiere decirse así) a quien va dirigida la orden. Podría decirse que el sujeto que soy, yo mismo, es aquel a quien la orden se dirige. Pero que es otro aquel que pronuncia la orden. Eso significa que el sujeto está, en el suceso moral, radicalmente escindido y partido entre un Sujeto Ajeno que enuncia la proposición y eso que soy, yo mismo, como receptor de la orden. ${ }^{9}$

Por lo que el acceso a la condición moral —a la genuina humana conditio, propia de una subjetividad definida por su índole fronteriza - y a su irrenunciable autonomía presupone una situación heterónoma originaria: literalmente, la ley es enunciada por una voz que viene de fuera e impone su exigencia a quien escucha. Pasividad indisociable de la experiencia de la culpa, manifestación primera y decisiva de la conciencia moral: «El fenómeno moral radical se recibe o se padece en el sujeto en forma de sentimiento y conciencia de culpa. Los términos duros e insoslayables de culpa y deber especifican el hecho moral. (...) No concibo una reflexión moral que no coja el toro por los cuernos, por los dos cuernos conceptuales y empíricos de la culpa y del deber.» ${ }^{10}$ Tal es el precio a pagar por la refundación ética de la subjetividad, pues solo la travesía de la culpa eleva al existente humano a su plena humanidad, con lo que la cesura entre facticidad y moralidad, entre ser y deber ser, se fragua en el encuentro entre el sujeto humano y la misteriosa alteridad que lo reclama. También aquel deviene irreversiblemente otro a resultas de esa cita. La tercera categoría (constitución del sujeto como fronterizo) es «categoría de pasaje; o de prueba iniciática; toda la vida del fronterizo tendrá desde entonces ese carácter». ${ }^{11}$

\footnotetext{
9 Los límites del mundo, op. cit., p. 47. Más radicalmente aún: "Allí donde hay hombre hay culpa» (ibid., p. 73). Tal sería el a priori ético-antropológico: solo el abandono de la inocencia animal franquea el acceso al estatus de fronterizo. Finitud trágica: como en la analítica existenciaria, la culpa se resuelve en experiencia de una deuda insaldable, deuda que se confunde con el propio ser de quien no advino a la existencia a resultas de un acto propio y está irremisiblemente condenado a abandonarla. Natalidad y mortalidad no solo marcan los límites cronológicos de la existencia fronteriza; determinan, ante todo, su consistencia ontológica: «De hecho ser constitutivamente deudor, o culpable, consiste en saberse fundado por un fundamento en quiebra, o ser portador fundamental de una "inanidad" que afecta a la propia condición fronteriza" (La razón fronteriza, op. cit., pp. 7071). De ahí la proclamada afinidad con aquellos pensadores que, no dispuestos a renunciar a la densidad moral de la culpa, supieron reconocer el pari metafísico de una ética consecuente consigo misma; Trías cita a Kant, al Heidegger de Sein und Zeit, al Wittgenstein de las páginas finales del Tractatus y al Freud tardío: "Creo que estos cuatro grandes pensadores percibieron, de forma instintiva algunos, otros de modo plenamente consciente, que el salto al suceso moral abre regiamente el acceso a la metafisica" (Los límites del mundo, op. cit., p. 48).

${ }^{10}$ Ibid.

11 El hilo de la verdad, op. cit., p. 127.
} 
¿Qué hay del sujeto de la voz, del emisor del imperativo? Nada puedo saber de él, pues rehúye toda determinación o identificación: «Ese sujeto es, pues, respecto a mí, un lugar vacio que se sitúa allende la frontera de mi experiencia». ${ }^{12}$ (Para nombrarlo, señala Trías, únicamente cabe recurrir a denominaciones «míticas», como Zeus más propio o Padre muerto, o bien echar mano de la enigmática expresión «voz de la conciencia»). Sin que ese no-saber sea mera ignorancia; tiene, muy el contrario, una significación decisiva, por cuanto la incognoscibilidad abre al sujeto una auténtica experiencia metafísica: frente al orden de lo intramundano, siempre al alcance de su curiosidad, emerge ahora un horizonte radicalmente distinto, el del cerco hermético, en absoluto cognoscible pero no por ello carente de relación con el fronterizo. De hecho, la metamorfosis que hace del sujeto humano un fronterizo ya no tiene lugar en el cerco del aparecer, sino que supone su elevación o alzado al lugar del límite o frontera, al cerco fronterizo. Desde este, es cierto, no cabe instalarse, de un salto, en el cerco hermético, pero sí escuchar la misteriosa emisión que de allí proviene y, en esa medida, obtener de ese ámbito cierta noticia.

Noticia auditiva, la encerrada en la voz de origen enigmático. Su estatuto es, por lo demás, extrańo y paradójico, contradictorio incluso, pues se trata de una voz silenciosa: «ese silencio paradójica y extrańamente nos habla a través de una voz que nada dice (en términos de representación concreta y material) pero que ordena». ${ }^{13}$ Hiper-kantismo de un imperativo categórico reducido al puro vacío de su forma desnuda; esa esencialización de la orden, no obstante, radicaliza la obligación impuesta al fronterizo, por más que de ella no brote mandato concreto alguno. Su función no consiste en proveerle de un repertorio de bienes o catálogo de deberes, susceptibles de inmediata traducción práctica en acción, sino conminarle a obrar un Bien de cuya naturaleza no recibe información alguna: «Pero ese imperativo solo dice imperativamente "obra el bien", sin que dé indicación ni testimonio, en el marco del aparecer, de ninguna aparición que encarne o personifique ese "bien" o su contrario.» ${ }^{14}$

Así pues, ¿a qué obliga el mandato que solo enuncia la forma pura del deber, el imperativo absolutizado? Ordena, ni más ni menos, que el fronterizo sea tal, fiel a su condición (bumana conditio), convirtiendo su ser en tarea, de tal modo que la con-vocación trascendente despierta la vocación fronteriza, sacando al humano del letargo animal en que lo sumió su caída en el cerco del aparecer. Cabría formularlo así: "Obra de tal manera que ajustes tu máxima de conducta, o de acción, a tu propia condición humana; es decir, a tu condición de habitante de la frontera”.. ${ }^{15}$

12 Los limites del mundo, op. cit., p. 53.

13 Los limites del mundo, op. cit., p. 49.

${ }^{14}$ La aventura filosófica, op. cit., p. 67.

${ }^{15}$ Ética y condición humana, op. cit., p. 16. 
Se trata, dice Trías, del imperativo pindárico, que ordena «llegar a ser lo que se es», o sea, fronterizo.

Nada más elocuente que ese silencio; nada, tampoco, más preñado de consecuencias. En él se halla en juego la posibilidad de la libertad, determinación mayor de la subjetividad limítrofe. Si el habla imperativa, en lugar de imponer la nuda exigencia del imperativo pindárico (séfronterizo; pero: ¿cómo?, ¿según qué normas?, ¿en qué acciones?... ninguna instrucción aclaratoria cabe esperar del sujeto que ordena), articulase un detallado programa de acción, la vida moral se vería abortada in statu nascendi, puesto que ya no sería obrar de un sujeto libre sino comportamiento de una voluntad esclava. Es, pues, el eclipse de la voz — la interrupción de la comunicación, como cuando «se corta» una conversación telefónica- ${ }^{16}$ condición de posibilidad de la libertad para el fronterizo, cuyo lugar está justamente en ese hiato o cesura entre dos cercos, el hermético (del que proviene la llamada) y el del aparecer (desde el que se yergue el receptor). Trías es tajante al reclamar un margen de incertidumbre para la acción moral; si esta derivase de un saber, al modo en que la conclusión lógica lo hace de las premisas del argumento, la libertad, garantía de indeterminación e imprevisibilidad, carecería de base ontológica: "O hay ciencia del bien y del mal o hay libertad. Como decían los escolásticos: tertium non datur.» ${ }^{17} \mathrm{El}$ pensamiento limítrofe, en virtud de la promoción del cerco fronterizo a la suprema dignidad ontológica, está en condiciones de fundamentar un querer libre. En última instancia, el imperativo vacío, urgiendo al fronterizo a ser leal a su naturaleza habitando el límite, no hace sino enunciar, en modulación ética, el propio límite:

Lo trágico de la frase estriba en el hiato y desgarrón irremediable, no-mediable, entre lo que la frase dice ("Obra el bien") y su cumplimiento fenoménico. Esa frase revela el gozne como gozne, o el límite como límite, como el lugar mismo que se aloja en ese hiato, el hiato entre el es y el debe, el hiato entre el indicativo y el imperativo. ${ }^{18}$

Si el límite o frontera es el único lugar apto para morada del sujeto ético, la localización resultante del imperativo excluye que pueda asentarse en cualquier otro territorio. Dos se postulan como posibles: por un lado, el situado aquende el límite, es decir, el cerco del aparecer, mundo de sucesos físicos remitidos a la matriz pre-mundana; por otro, el ubicado allende el límite, el cerco hermético que, siendo estación emisora de la orden, se retrae en su secreto. En consecuencia, el imperativo

\footnotetext{
16 «La primera parte de la frase es pronunciada desde allende el cerco y la frontera. Luego la comunicación se interrumpe. Esa interrupción, ese hiato telefónico funda radicalmente mi libertad» (Los límites del mundo, op. cit., p. 50). «La indeterminación material de la orden abre, pues, cauce a mi libertad: la instituye y funda. Y a través de ello consumo la experiencia ética trascendental» (ibid.)

${ }_{17}$ Ética y condición humana, op. cit., p. 76.

${ }^{18}$ La aventura filosófica, op. cit., p. 74.
} 
pindárico contiene, implícitamente, dos corolarios, ambos de signo negativo: la fidelidad del fronterizo a su propia condición le prohíbe tanto el retorno al cerco físico (del que sin duda proviene, como animal que es), y más aún a la salvaje matriz que lo soporta, cuanto la irrupción en el cerco hermético. Ha de ser hombre, ni más (divinidad supra-humana) ni menos (animalidad infra-humana); animalización y divinización son incompatibles con su destino:

Nuestra condición limítrofe y fronteriza nos sitúa a infinita distancia de la naturaleza (pre-humana) y del misterio (supra-humano). Nuestra condición marca sus diferencias en relación a lo físico (la vida vegetal o animal) y en relación a lo metafísico o teológico (la vida divina). ${ }^{19}$

Pero el doble veto ha de ser indicio de una dúplice tendencia en el sujeto fronterizo, siendo en tal medida el límite lugar de tentación o hybris: lo exigido por toda norma moral (o jurídica) contraría la voluntad del sujeto a ella sometido. ¿ Se inclina el querer humano en la doble dirección que lo alejaría sin remisión de su hogar fronterizo? Así es, en efecto. Por una parte, le acucia el deseo o pulsión incestuosa del amor-pasión, que no es, en última instancia, sino afán de retorno al principio materno o matricial, fundiéndose en amoroso abrazo con el sombrío sustrato del que brota lo mundano, como si le fuese dado invertir el tiempo y verse devuelto al lugar abandonado al nacer. Pero, por otra parte, excita al fronterizo la desmesurada ambición de trascender su índole mortal y usurpar el lugar del Padre muerto (ausencia emisora de la voz), instituyéndose en detentador de un poder omnímodo al que habría de someterse cualquier otro sujeto. Oscuro regreso al regazo de una magna mater y libido dominandi de una potencia sin límites, incesto y parricidio, atracción por la Diosa Erda o por la Voz del Padre Muerto, ${ }^{20}$ en ambas inclinaciones reconoce el fronterizo la verdad de su deseo, al que dan expresión lógico-lingüística dos falacias, la naturalista (reducción de lo ético a la matriz pre-mundana) y la meta-lingüística (delirio totalitario de una ética que quiere ocupar un lugar absoluto, más allá de mundo y lenguaje). ${ }^{21}$ Pero el rendimiento del imperativo consiste, precisamente, en impedir ambas formas de extravío ratificando así el lugar ético, ni matricial ni meta-mundano, del límite:

El lugar del padre muerto y sepultado, el lugar del Dios oculto en el subsuelo infernal del otro mundo, debe dejarse vacío (el sepulcro está vacío). El lugar de la tierra madre o de la figura materna de la patria está escondido y retirado: debe dejarse, piadosa, modestamente, en ese retiro y autoolvido. ${ }^{22}$

\footnotetext{
Ética y condición humana, op. cit., p. 13.

${ }^{20}$ Cf. Los limites del mundo, op. cit., p. 71.

${ }^{21}$ Cf. Ética y condición humana, op. cit., pp. 65-66.

22 Los limites del mundo, op. cit., p. 69.
} 
Por registrar sin ambages el sustrato pasional de la vida moral (toda ética es, en su velado o inconfeso origen, una patética; el ethos nace — viene repitiendo Eugenio Trías desde su Tratado de la pasión - de la pasión antes que de la acción), ${ }^{23}$ la ética limítrofe reivindica un carácter trágico e invita a pensar el núcleo fundante de la acción desde «la intersección misma, o cruce, o entrecruzamiento de pasión y logos, de padecimiento y lenguaje, al que aquí se llama compromiso lingüístico-pasional». ${ }^{24}$ Pero ese compromiso no lo es con la hybris del héroe abrumado por el destino, sino con la sabiduría trágica que hace del límite o medida único antídoto eficaz contra la desmesura de aquel. De Esquilo y Sófocles aprendemos, en la desventura de la víctima, una sabiduría cuya destilación suprema ofrece la palabra del filósofo:

La vida es buena cuando es acorde con esa humana conditio que aquí es propuesta; cuando sabe determinar el carácter indeterminado de esa condición nuestra mediante la de-terminación de su doble indeterminación (por defecto o exceso); cuando espanta ese defecto y ese exceso en el mesótes (aristotélico), o ese "justo medio" que salvaguarda de una inhumanidad por defecto (por apego a la matriz) o por exceso (por voluntad de dominación). ${ }^{25}$

«El sujeto, por tanto, comparece como "un límite del mundo" (Wittgenstein): desdoblado entre esa parte de sí mismo que comparece como una voz (imperativa) procedente de más allá del límite del mundo, y esa otra parte que constituye su afincamiento en el cerco del aparecer, o en el ámbito intramundano.» ${ }^{26} \mathrm{~A}$ medida que el discurso penetra en la sustancia del acontecimiento ético, va dejando constancia de la complejidad inherente a la subjetividad que le corresponde. Mayor aún de lo consignado hasta ahora. A los dos personajes ya conocidos (el emisor de la voz imperativa, arraigado en el cerco hermético, y el oyente de la misma, que abandona su ubicación primitiva en el cerco del aparecer para domiciliarse en el cerco fronterizo, pues solo en este puede la audición tener lugar) ha de añadírseles un tercero, el de quien tiene encomendada la misión de dar respuesta en forma de praxis a la exigencia del imperativo pindárico, por lo que se ve devuelto al cerco del aparecer en

\footnotetext{
23 «La pasión no es pasión de un sujeto sino que, desde ella, funda toda "sujeción” como subjetividad pasional. El sujeto lo es como derivación de la pasión que le domina” (Lógica del límite, op. cit., p. 459).

${ }^{24}$ Lógica del límite, op. cit., p. 464.

25 Ciudad sobre ciudad, op. cit., pp. 243-244.

${ }^{26}$ La razón fronteriza, op. cit., p. 71. (Adviértase que el sujeto otro — su trascendencia o alteridad era subrayada por Los limites del mundo — aparece aquí como "parte» hermética del sujeto limítrofe. Ese cambio de acento será abordado con posterioridad).
} 
tanto que ámbito donde un curso de acción puede materializarse. Ética y condición humana propone denominar a esas tres figuras Sujeto 1, Sujeto 2 y Sujeto 3. Resulta obvio que esa tríada es trasunto ético-antropológico de la trinidad ontológica (confirmación del principio rector de la filosofía del límite: cada sector de la experiencia humana - los cuatro barrios o distritos de la ciudad fronteriza - debe ser explorado en función de la ontología trágica y su fundamento topológico), dado que cada nivel de subjetividad se configura en estrecha ligazón con uno de los cercos: la voz que pronuncia la orden (Sujeto 1) emite desde el cerco hermético; el receptor (Sujeto 2) solo accede a ser tal mediante el previo alzado al cerco limítrofe, fuera del cual ninguna audición resulta posible; en cuanto al agente (Sujeto 3), opera en el cerco del aparecer, en relación con otros humanos y con los demás existentes intramundanos. También en clave cronológica puede glosarse lo ético, dado que la triplicidad de sujetos y cercos instituye igualmente una secuencia de tres tiempos: el de la propuesta (Sujeto 1), el de la escucha (Sujeto 2) y el de la respuesta (Sujeto 3). ${ }^{27}$

Con todo, siendo todas ellas imprescindibles, no es menos cierto que una de las tres figuras de la subjetividad prevalece sobre las dos restantes. Nos referimos, naturalmente, al Sujeto 2, a quien conviene el nombre de fronterizo. ¿Cabe ver en ello una confirmación de la hegemonía de la noción de límite en el dispositivo ontológico (el espacio fronterizo permite determinar los otros dos cercos como su aquende y su allende) y topológico (del Límite como instancia fundadora, cuya unidad se desdobla internamente, provienen los tres cercos) de Trías? Así es, sin duda: la primacía onto-topológica del límite tiene su trasunto ético-antropológico en el predominio o hegemonía del Sujeto 2; al igual que el cerco limítrofe remite, en virtud de su propia consistencia ontológica, al del aparecer y al hermético (a diferencia de la clausura de cada uno de ellos en su propio espacio: aquel, en la inmanencia del fenómeno que se muestra; este, en el repliegue de lo misterioso), el Sujeto 2 proporciona el nexo entre la llamada del Sujeto 1 y su ejecución por el Sujeto 3. No en vano el nombre del ser humano es, en esta filosofía, el de fronterizo. De los limitanei se impone decir:

Se caracterizan por su naturaleza centáurica, a caballo entre el mundo y el misterio, o entre el cerco del aparecer y el arcano. Son los hijos del humus, los "humildes", que acceden a la "humanización" toda vez que se reconocen habitantes del lugar del límite. ${ }^{28}$

La imagen del centauro como emblema o símbolo de una condición — humana conditio - referida al misterio que, sin dejar de serle íntimo, la trasciende y a una animalidad que, aun incorporándose a su sustancia, ha de ser excedida parece

\footnotetext{
${ }^{27}$ Cf. Ciudad sobre ciudad, op. cit., pp. 239-240.

28 La razón fronteriza, op. cit., p. 248.
} 
trabajar en profundidad el imaginario filosófico de Trías. ${ }^{29}$ Desde fecha temprana: el ensayo "Pico della Mirandola: El hombre, semejante a Proteo» ${ }^{30}$ perfilaba ya a mediados de los setenta un proyecto de antropología centrada en la excentricidad de la anomalía ontológica constituyente de lo humano, y en el juego especular entre microcosmos y macrocosmos, al hilo de un comentario de ese texto fundacional que es la Oratio de hominis dignitate del neoplatónico renacentista:

¿Qué extraña cosa es el hombre? ¿Qué rareza o extravagancia permite comprender su etérea y tornadiza naturaleza? Pico della Mirandola responde: semejante a un gran camaleón, semejante a Proteo, el hombre, precisamente porque no es ninguna cosa, puede ser todas las cosas. ${ }^{31}$

Esa intrincada estructura (en interrelación: la subjetividad fronteriza incorpora tanto una estática — distinción de tres estratos- como una dinámica — comercio mutuo entre los tres niveles-, paralela esta última a la presión recíproca ejercida por los cercos) aporta luz a la naturaleza del acontecimiento ético. Se da en él un elemento irreductiblemente metafísico, no susceptible, por tanto, de la enunciación o cognición vigentes en el cerco del aparecer. El Sujeto 1 debe ser mantenido en el encierro propio de lo hermético, evitando la ilusión trascendental que haría de él objeto de un discurso apto para nombrar la esencia de su referente. Apenas el silencio, un respetuoso silencio, parece compatible con la escucha de la voz misteriosa:

Pero esa raíz está implantada en tierra extrańa. La voz llega a mí del extranjero. Del reino de los muertos proviene la voz de orden. En el sepulcro en donde yacen los ancestros,

${ }^{29}$ No en vano califica de "perla filosófica de gran calado» el sintagma orteguiano, «el hombre, ese centauro ontológico». Cf. El hilo de la verdad, op. cit., p. 53.

${ }^{30}$ Cf. El artista y la ciudad, Barcelona, Anagrama, $1983^{2}$, pp. 75-83.

31 El artista y la ciudad, op. cit., p. 78. Del interés de Trías por la meditación del humanista florentino son también muestra la entrada «Hombre» del Diccionario del espiritu (Barcelona, Planeta, 1996, pp. 73-78) y las referencias presentes en "El cuadro que nunca fue pintado» (Lo bello y lo siniestro, Barcelona, Ariel, 1988, pp. 47-78). No estará de más recordar que E. H. Gombrich, en su clásico estudio iconológico "Las mitologías de Botticelli» (Imágenes simbólicas, trad. de R. Gómez Díaz, Madrid, Alianza Editorial, 1983, pp. 63-130), analiza el centauro del lienzo Palas y el Centauro como símbolo antropológico, pues en esa figura mitológica coexisten los dos ingredientes de lo humano, animalidad y racionalidad: los tres niveles que Platón tematiza en el alma humana aparecerían, en representación pictórica, mediante Minerva (caput aurigae), lo humano del Centauro (melior equus) y su parte equina (equus deterior). Cf. E. H. Gombrich, op. cit., p. 314 (nota 146). Seńalemos, para terminar, que Trías, proclive a una lectura retrospectiva de su producción en clave continuista (y a rastrear los precedentes histórico-filosóficos de la filosofía del límite), conecta explícitamente el paradigma antropológico de Pico con su propia teorización del fronterizo: «Y ese carácter excéntrico, recordado ya por el gran pensador renacentista Pico della Mirandola, constituye, como supo afirmar este en su célebre Oración sobre la dignidad humana, el fundamento de nuestra libertad. Ya que desde ese límite o confín, que no es una línea (como pensaba Heidegger) sino una franja habitable, podemos determinar nuestra vida, nuestra acción y nuestra praxis; y en dirección hacia una insistencia vital y convivencial que consiste en tomarle la medida al limes; o en la libre y abierta posibilidad de arruinarnos al ser y al sentido por no comprender esa medida limítrofe, o por querer ilusoriamente rebasarla» (El hilo de la verdad, op. cit., p. 55). 
los dioses muertos, se halla el lugar en el cual puede definirse y localizarse el "sujeto" que emite la voz de orden. ${ }^{32}$

Es justamente la renuncia a ocupar ese lugar vacío, ateniéndose a la propia vocación fronteriza, lo que distingue una ética racional e ilustrada (consciente de recibir una palabra procedente del cerco hermético, asume que tanto la escucha como la respuesta se producen fuera de aquel, por siempre inaccesible) de otra irracional o dogmática (empeñada en ocupar ese vacío, implantándose en el más allá del límite). En ese sentido, cabría decir que la ética fronteriza propone, more kantiano, un uso del Sujeto 1 como concepto-límite, pues esa instancia únicamente permite designar un lugar vacío. Se tiene noticia de Algo que emite la orden, pero se sabe también que ha de mantenerse irrepresentable. Tal es el compromiso iconoclasta de una ética limítrofe, único modo de garantizar la libertad finita del habitante de la frontera.

Pero lo irrepresentable profiere el enunciado imperativo y con ello, sin merma de su incondicional incognoscibilidad, entra en relación con quien, en virtud de esa interpelación, accede al límite y deviene fronterizo. Cita o encuentro entre aquello que, sin comparecer como presencia, habla desde el cerco hermético y aquel que, elevándose desde el cerco del aparecer, alcanza el cerco limítrofe. Así se constituye el Sujeto 2:

Esa frase instituye al fronterizo como fronterizo. Porque "oye" esa frase, por lo demás partida y dividida, por eso es lo que es, límite y gozne entre dos ámbitos de "infinita distancia". La frase está, en efecto, dividida y escindida, ya que solo "llega", como mensaje, al fronterizo, la primera parte de la frase, la que exige u obliga al fronterizo a obrar de una determinada manera (obrar "bien") sin que pueda, en cambio, oírse el contenido material que "se dice" después de ese comienzo de la frase. ${ }^{33}$

Pero el inacabamiento del imperativo, la interrupción de la comunicación, reclama una instancia suplementaria, la del Sujeto 3. Se le encomienda completar la frase inconclusa y responder a la demanda mediante un curso de acción: «He de materializar en el hacer eso (indecible) que no me es posible decir.» ${ }^{34}$ En su mera formalidad, el imperativo obliga de manera categórica, pero no enuncia ningún curso de acción definido; tan solo impone un "debes...» ayuno de contenido material. Proporcionarlo es incumbencia del Sujeto 3. En él se invierte el dinamismo inaugural de lo ético: si en un primer momento aconteció un alzado — del cerco del aparecer al fronterizo - , ahora ha de tener lugar un descenso — del cerco fronterizo

32 Los limites del mundo, op. cit., p. 54.

${ }^{33}$ La aventura filosófica, op. cit., p. 74.

${ }^{34}$ Los límites del mundo, op. cit., p. 59. "Eso indecible de allende el límite no puede ser propuesto (en enunciados declarativos, o "apofánticos"); pero puede y debe ser actuado" (La razón fronteriza, op. cit., p. 67). 
al del aparecer-, por más que quien vuelve ya no es idéntico, aunque se trate del mismo sujeto, a quien fue llamado — en realidad, reclamado - por la proposición del Sujeto 1. El existente humano ha dejado de ser ente intramundano, que reconocía en el cerco del aparecer su único ámbito de vida, y se ha vuelto fronterizo (Sujeto 2) que, tras oír el imperativo trascendente, se dispone a darle cumplimiento en un obrar inscrito en el tejido el mundo (Sujeto 3).

En virtud de la estratificación tripartita de la subjetividad, la ética limítrofe puede dar cuenta tanto de la universalidad irrestricta del imperativo (la proposición ética del Sujeto 1 obliga incondicionalmente a todo sujeto convertido en fronterizo) como de la irrenunciable concreción (circunstancias de la acción; contexto social e histórico) en que ha de materializarse la praxis del Sujeto 3, tanto de la obligatoriedad absoluta de la orden como de la paradójica libertad de quien la acata, tanto de la impersonalidad de lo ordenado (el mandato se dirige a cualquier fronterizo, al que instituye en su humana conditio) como de la singularidad o individualidad de la respuesta:

Esa materialización, que es el resultado de una libre elección y decisión, o de una libre respuesta a la propuesta, admite y acoge tantas orientaciones de la acción como sujetos o agentes (personales, individuales) existan. A la unidad, unicidad y universalidad incondicional de la propuesta sigue la pluralidad dispersa y diversa de las respuestas. ${ }^{35}$

Nada de todo ello sería posible sin el hiato fundacional entre la exigencia y su traducción práctica (correlato de la función ontológica del cerco limítrofe como franja separadora de patencia fenoménica y latencia hermética), pues en él se aloja la libertad del fronterizo. A contrapelo del conocido adagio, la ética fronteriza proclama que el dios propone y el hombre dispone. La creatividad ética supone el asentamiento de la voluntad (Sujeto 2) en el límite o frontera, desde donde cabe escuchar la exigencia nouménica (Sujeto 1) y otorgarle respuesta —-formulación de normas morales, dotadas de contenido axiológico, y compromiso con ellas en la praxis - en el campo fenoménico (Sujeto 3). Por otro lado, esa vocación limítrofe invita a conciliar, en síntesis armónica, el legado ético de la Antigüedad (la buena vida como telos de la acción) y la demanda moderna de libertad (formalismo ético), mediando entre la sabiduría práctica de Aristóteles y el primado kantiano de una voluntad autónoma. Pues lo ético requiere por igual forma (autodeterminación o autonomía de un sujeto libre) y finalidad (buena vida como supremo objetivo ético). Doble faz, desde la nueva ética del límite, de un solo principio, el limes mismo:

35 Ética y condición humana, op. cit., pp. 47-48. Esa mediación permite conciliar la tensa bipolaridad, definitoria del ámbito ético, entre prescripción absoluta y contingencia de las condiciones objetivas; dicho en términos histórico-filosóficos, entre rigorismo kantiano y ética prudencial aristotélica. Cf. Ética y condición humana, op. cit., p. 38. 
Pero tanto la forma como la finalidad muestran lo mismo: la misma condición limítrofe, que en la forma comparece como proposición imperativa ética, y en la finalidad se muestra como efecto del cumplimiento de esta (la vida venturosa, la buena vida). ${ }^{36}$

Una persistente e irresuelta ambigüedad ha atravesado nuestro recorrido por el territorio ético, articulado como espacio de juego entre tres niveles de subjetividad (los sujetos 1, 2 y 3). Su necesaria distinción no plantea dudas en el paradigma de Trías, pero sí resulta problemático el estatuto óntico que haya de atribuírsele: ¿se trata de tres sujetos diferenciados o de tres estratos de una subjetividad única? ¿ ¿Ha de entenderse la tríada como genuina intersubjetividad o más bien como dinámica intrasubjetiva? ¿Propone el autor de Los límites del mundo una diferencia sustantiva o meramente funcional? En lo que a los sujetos 2 y 3 respecta, la respuesta parece clara: por mucho que se insista en su distinción (pareja a la duplicidad de cercos; respectivamente, el limítrofe y el del aparecer), queda clara la identidad de referente, pues fronterizo y agente nombran aspectos o funciones de un sujeto único (el que, alzándose al cerco limítrofe, escucha la orden no es otro que quien la cumple emprendiendo un curso de acción; yo mismo soy ambos, según dos registros de mi vida subjetiva). Pero la identidad del Sujeto 1, en su relación con los dos restantes, resulta mucho más enigmática, algo acorde, por lo demás, con su ubicación en el cerco hermético, es decir, en el lugar del misterio. ${ }^{37}$

\footnotetext{
${ }^{36}$ Ética y condición humana, op. cit., p. 60.

37 Si de la elaboración discursiva de la subjetividad ética transitamos a su posible plasmación pictórica (en el ya aludido lienzo de Sandro Botticelli Palas y el Centauro), el enigma persiste: dando por buena la interpretación de Gombrich (es decir, admitiendo que ese cuadro no sea sino traducción icónica de la doctrina platónica de un alma tripartita: racional —Palas_, irascible — parte humana del centauro_ y concupiscible — parte animal del centauro-), nos inclinaríamos hacia una lectura monista, pero sin que por ello pudiésemos soslayar el hecho, plásticamente incuestionable, de que en la superficie pintada figuran dos personajes (uno de ellos, el centáurico, a su vez doble) y no uno solo. Se impone reconocer que la figura presente a la derecha del espectador representa una divinidad (Palas Atenea; Minerva), en contraste con el otro protagonista, semihumano y semibestial. Esta breve digresión no nos aleja del centro del interés especulativo de Trías. Y no solo por la hondura de su fidelidad a Platón o el rigor con que «El cuadro que nunca fue pintado» identifica en el consorcio Ficino-Botticelli la expresión filosófico-plástica de una intuición antropológica cuya formulación platónica y neoplatónica nunca ha dejado de inspirar la propia tematización triasiana de lo humano. Hay una razón adicional de peso para invocar ese cuadro: en él tiene lugar una escena moral en la que la diosa Minerva somete o "doma" (recuérdese el título italiano del cuadro: Pallade che doma il centauro), transformándolo, a un ser compuesto de dos elementos, salvaje uno y más proclive el otro a prestar oídos a la figura divina que le mira y retiene sus cabellos. ¿̨No delatará la mitad caballar su arraigo en la naturaleza y su matriz pre-mundana, al igual que la mitad humana simbolizaría la condición fronteriza? Pero, en tal caso, ¿cómo entender en perspectiva ético-antropológica la figura celeste de
} 


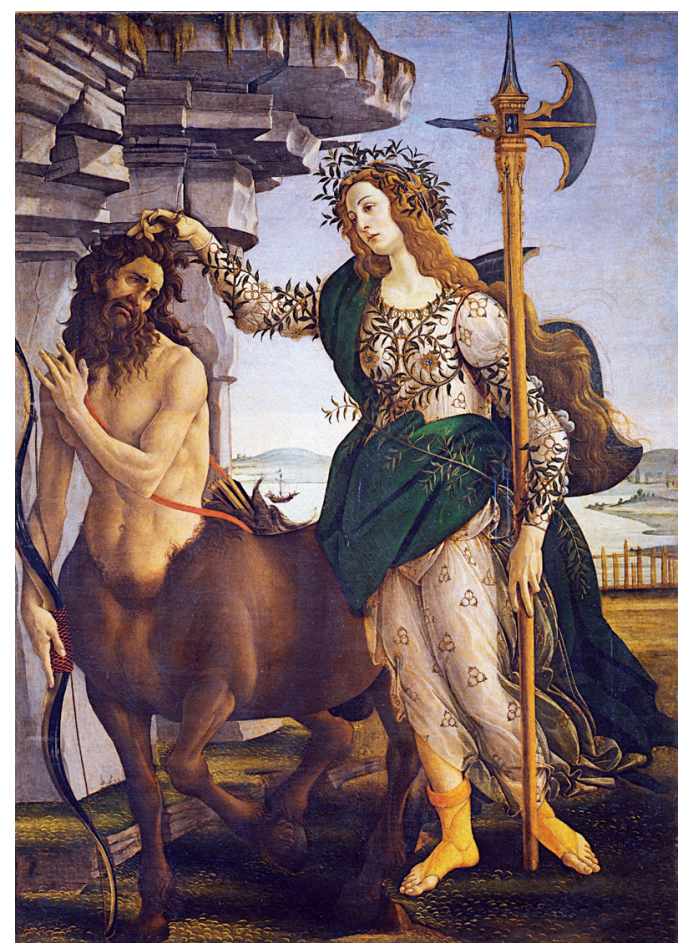

Palas y el centauro (Sandro Botticelli; 1482) ${ }^{38}$

La tercera categoría transcribe un encuentro o cita. ¿Entre el humano fronterizo (Sujeto 2) y la divinidad (Sujeto 1) que hace oír su voz desde el cerco hermético? ¿O más bien se trata de un «diálogo del alma consigo misma», de un íntimo desdoblamiento del sujeto humano? Ninguna duda puede caber sobre la incidencia en el acontecimiento ético de los dos cercos, fronterizo y hermético; pero, aun así, subsiste la pregunta: ¿su encuentro acaece en la inmanencia antropológica - lo humano, puramente humano - o supone un espacio mixto de relación entre lo humano y lo divino? Con otras palabras: ¿cabe dar cuenta de lo ético en clave exclusivamente antropológica o su elucidación obliga a transitar senderos metafísico-religiosos? ¿ $\mathrm{O}$ quizá resulte artificial el dilema, por cuanto la propia condición humana, definitoria del ser fronterizo, incluiría de suyo irrenunciables momentos metafísicos

Palas o Minerva sino como sujeto emisor de la voz proveniente del cerco hermético, cuya dócil escucha representaría la mansedumbre del centauro?

38 Tomada de https://arte.laguia2000.com/pintura/palas-y-el-centauro-de-botticelli 
que ponen en entredicho un recurso excesivamente escolar a dicotomías rígidas (inmanencia vs. trascendencia; profano vs. religioso; humano vs. divino)? Acaso el efecto mayor de la filosofía del límite sea perturbar hábitos intelectuales demasiado acomodaticios, obligando a reformular, desde una novedosa inspiración, viejas preguntas, en lugar de conformarse con seleccionar una de las respuestas disponibles en repertorios tradicionales. Quizá sea así. En cualquier caso, no nos apresuremos.

Partamos de una constatación: la ambigüedad está en el propio discurso de Trías. Por un lado (sobre todo en el texto inaugural, Los límites del mundo, donde, como hemos podido comprobar, se insiste en la inconmensurabilidad entre emisor y receptor de la frase imperativa o proposición ética: mientras que el primero ostenta un carácter genuinamente metafísico y tiene su morada en el cerco hermético, el segundo no es sino el sujeto humano que, proveniente del cerco físico, se alza al límite o frontera; desde aquí cabe prestar oídos a la voz, pero no representarse a quien la pronuncia), radicaliza la trascendencia de la instancia hermética, en acusado - y dualístico- contraste con el oyente fronterizo. Pero, por otro lado (de forma creciente a medida que nos acercamos a los textos tardíos, que sin duda mantienen el esquema del acontecimiento ético trazado en Los límites del mundo, pero que no por ello dejan de enriquecerlo y recrearlo), a cada paso se impone con mayor claridad que la triplicidad de figuras éticas remite a sendos niveles antropológicos. Como si de la trascendencia acentuada (no sin ambigüedad, es cierto: respecto a lo hermético domina siempre un acercamiento discreto, que rehúye la explicitud; algo patente en la consideración de los nombres de la instancia trascendente - Padre muerto o Zeus más propio- como denominaciones «míticas», a manera de pseudónimos que vanamente pretenderían nombrar lo que ha de permanecer innominado) pudiese transitarse con naturalidad a su inscripción antropológica. Obsérvese cómo ya en La aventura filosófica la proclamación de la escisión meta-física entre sujetos da paso, sin solución de continuidad, al desdoblamiento en dos mitades, hermética y fronteriza, de un sujeto único:

Dice algo al fronterizo como fronterizo. (...) Ese decir se muestra como una "voz" cuyo sujeto está escindido de aquel a quien eso se dice (el fronterizo). Esa "voz" es, en relación al "yo" del fronterizo, un Ueberich, un super-ego, la mitad oculta, encerrada en sí de su propia subjetividad, su dimensión absorbida dentro del cerco nouménico. ${ }^{39}$

El sujeto otro o extraño, aunque no por ello cese de domiciliarse en el cerco hermético, revela ahora su condición de parte o «mitad oculta» de la subjetividad limítrofe, como si la categoría de Otro se subordinase, en el ámbito ético, a la de

39 La aventura filosófica, op. cit, p. 66. 
Mismo, obligando por tanto a reformular la distinción entre Sujeto 1 y Sujeto 2 en términos más monistas que dualistas. Eso es lo que se impone con creciente evidencia en las formulaciones más recientes de la ética limítrofe: el Sujeto 1 «constituye una instancia topológica del propio sujeto del límite (...), uno de los componentes que hace posible la cita y el encuentro del sujeto consigo»; ${ }^{40}$ " forma parte de ese sujeto que somos», en lugar de representar «una suerte de instancia heterónoma o alógena en relación a nuestra experiencia»; ${ }^{41}$ es «el lado excedente del propio sujeto fronterizo desdoblado». ${ }^{42}$ Con todo, esa evidencia textual no parece anular la ambigüedad o tensión internas de un planteamiento especulativo comprometido por igual con el estatuto metafísico de la instancia legisladora y la necesidad de integrar en la realidad antropológica toda la sustancia del acontecimiento moral. ${ }^{43}$

Se impone, por tanto, preguntar: ¡cómo pueden conciliarse, con plena coherencia discursiva, la afirmación de la trascendencia inherente al Sujeto 1 con su inclusión en la subjetividad fronteriza (en lo que cabría denominar el plano de inmanencia antropológico)? Reconociendo que se trata de un problema harto difícil, consideramos que Trías aporta dos claves valiosísimas para su resolución. La primera, de naturaleza onto-topológica, obliga a indagar la fuente última de inteligibilidad del hecho moral en la pura noción de Límite. Metafísica, la segunda se adentra en el núcleo acaso más íntimo de la experiencia religiosa, inmersa en la antinomia entre extrañeza u otredad de la divinidad que se revela y deificación del testigo humano que acoge la teofanía; esa aporía alcanza su máxima intensidad en aquellos momentos en que la conciencia religiosa se abre (en misticismos y angelologías, pero también en la postulación cristiana de la encarnación del Hijo) a cierta indistinción entre lo humano y lo divino.

Comencemos por la clave onto-topológica. Conviene recordar que la ética no es sino uno de los barrios de la ciudad fronteriza. Como tal, posee su idiosincrasia, pero sin que por ello acuse en menor grado la condición de parte o sector de un todo más

${ }^{40}$ Ciudad sobre ciudad, op. cit., p. 239.

41 El hilo de la verdad, op. cit., p. 94.

42 Ética y condición humana, op. cit., p. 186.

43 En los siguientes términos respondía Trías a sendos comentarios epistolares del autor relativos al enfoque del problema que nos ocupa en Ética y condición humana y El hilo de la verdad: «Entiendo el problema que me plantea, relativo al Sujeto 1. Yo mismo, este verano, he estado "luchando" con él (al estilo de Jacob con el ángel, o con el propio Yahveh). El caso es que quería mantener la máxima autonomía posible (pero siempre relativa) para el espacio ético, o para el quartier de la razón fronteriza en su uso práctico (...). Quería llevar hasta el máximo eso que usted ha adivinado, la suerte de dialéctica que en la ética se produce entre autonomía y heteronomía. Me importaba mantener en el máximo de sobriedad y discreción al referente (silencioso) que constituye ese Sujeto 1 que sostiene o soporta la "frase" ético-metafísica» (carta del 19 de septiembre de 2001); «Entiendo perfectamente sus interrogaciones finales. La relativa a la posible heteronomía del sujeto 1, por ejemplo. Lo cierto es que no puedo dejar de plantear las cosas en términos que a la fuerza pueden parecer ambiguos. Creo que la ambigüedad no está en mí; está en "la cosa”" (carta del 31 de agosto de 2004). 
amplio. De ello se sigue que la reflexión filosófica sobre el acontecimiento ético no puede prescindir de una fundamentación ontológica. Así, en el trecho ya recorrido hemos puesto de manifiesto la relevancia ética de la ontología trágica, cuyos tres cercos (del aparecer, limítrofe y hermético) permitieron definir una tríada de instancias éticas (los sujetos 3, 2 y 1). Por otro lado, la tercera categoría se reveló decisiva para dar cuenta de la constitución del espacio ético. Sin embargo, representa solo uno entre siete elementos de una tabla cuya serie culmina en la séptima categoría, la de ser del límite, que ilumina el sentido de sus seis predecesoras. También de la tercera; vale decir, del acontecimiento ético. Si este se inaugura con una enigmática voz que requiere al sujeto humano desde el cerco hermético, la identidad de su emisor únicamente puede desvelarse en la consumación del despliegue categorial:

Podría decirse que en la tercera categoría comparece lo que en Ética y condición humana llamo Sujeto 2 (situado en el cerco fronterizo; en el instante de recepción y audición de la "voz" en el que el ser del limite se "propone"). Y que en la séptima se descubre, con dificultad, el sujeto elíptico de la "frase" ético-filosófica, la que propone de forma imperativa, llegar a ser lo que se es (habitante de la frontera). ${ }^{44}$

Sin embargo, aun el análisis de la última categoría resulta, a la postre, insuficiente, por cuanto la ontología trágica de los tres cercos (lo sintetizado en la noción de ser del limite) no aporta la fundamentación última. ${ }^{45}$ Esta es competencia de la reflexión topológica, cuyo objeto es el Límite qua Absoluto, por cuanto su reflexividad interna, en la que juegan en reciprocidad los géneros supremos de lo Mismo y lo Otro, da cuenta de la triplicidad de cercos: nacen del propio desdoblamiento de la Unidad originaria (en sentido absoluto: nada cabe pensar como previo al Límite) en un anverso luminoso (cerco del aparecer) y un reverso sombrío (cerco hermético), entre los cuales tercia el territorio intermedio (cerco limítrofe). Más allá del ser, el Limite como espacio-luz: la especulación de Trías, al promover la idea de límite a la máxima dignidad filosófica, no se limita a reivindicar su lugar en la ontología (eso es, a fin de cuentas, lo que la doctrina del triple cerco le reconoce); reclama para ella la condición de Principio supremo o Fundamento incondicionado del que brotan, a título de proyecciones suyas, los tres cercos. De ese modo puede Trías ofrecer una propuesta que es a la vez pluralista (tres cercos) y monista (Límite o espacio-luz como fuente única de aquellos). Precisemos: pluralista en ontología y monista en

\footnotetext{
${ }_{44}$ El hilo de la verdad, op. cit., p. 94.

45 «En este sentido las raíces de la proposición ética son ontológicas. Solo que la ontología del límite se resuelve, en última instancia, en una topología radical ceñida y circunscrita a la Idea misma de Límite (concebido este en significación intrínseca y reflexiva, o como fundamento desde el cual se expide el ser, como ser del límite)" (Ética y condición humana, op. cit., 103).
} 
topología. Pues bien, es esa conciliación de unidad topológica y pluralidad ontológica lo que nos permite pensar a un tiempo una subjetividad ética escindida en tres sujetos y unificada como fundamento de su despliegue. Pues lo ético-antropológico, al igual que cualquiera de los otros barrios, no es sino trasunto de la Unidad topológica de la que todo (no solo los entes intramundanos, cuya suma es el cerco del aparecer; también los otros dos cercos) proviene. Si la topología es reflexión sobre el límite, sobre el lugar del límite, este constituye, en efecto, el lugar enigmático donde hemos de ubicar al Sujeto 1:

Esa barra designa el límite; es el signo que lo designa. Constituye su cifra misma. Y ese límite, en esta espiral reflexiva (relativa a la esencia del ser del límite), albergaría el sujeto de la enunciación, o de la proposición. No el sujeto en el sentido de aquel a quien se le da el ser (con la existencia) y el límite (como lugar de prueba de su libertad). Sería el sujeto (= x) de ese mismo límite que da ser y se recrea.

Ese sujeto se reconoce, por el momento, en su elipsis. Solo puede promoverse una aproximación a él por razonamientos indirectos, o metonímicos, o a través de formas simbólicas. Sería el sujeto $(=\mathrm{x})$ del límite. (...)

Ese sujeto forma parte de ese sujeto que somos. Pero de ningún modo es reductible a esa condición (humana, fronteriza) en la que nos reconocemos existiendo. Ese sujeto posee una peculiar ambivalencia; o se caracteriza por su intrínseca anfibología.

Es a la vez esa "parte" de nosotros mismos capaz de oír y recibir la apelación (imperativa) que nos conmina a llegar a ser lo que somos; y es también el incógnito $(=\mathrm{x})$ de donde esa "voz" puede, en nosotros, alcanzar pronunciamiento y expresión. ${ }^{46}$

De tal suerte que lo ontológico y lo ético se dan, desde su compartida raíz topológica, en íntima conexión, hasta el punto de unificarse la proposición (ontológica) que nombra el ser del límite y la proposición (ética) que, en forma imperativa, provoca el alzado del sujeto humano a la condición fronteriza:

Ese sujeto (1) es el sujeto ( $\mathrm{x}$ ) de la proposición ontológica. Que es, a la vez, declaración de la verdad del ser del límite, y propuesta (imperativa) que reta a la libertad del sujeto que inviste el límite.

$\mathrm{Y}$ es que esa proposición ontológica es, de hecho y de derecho, proposición ético-ontológica. ${ }^{47}$

La inspiración limítrofe hace posible pensar una subjetividad a la par tripartita y unitaria. Ahora bien, en el horizonte finito de experiencia del sujeto fronterizo el orden de la escisión resulta irrebasable, dado que el postulado de la unidad no anula la disimetría con que la terna de sujetos se presenta. Hay cita o encuentro entre Su-

\footnotetext{
${ }^{46}$ El hilo de la verdad, op. cit., pp. 114-115.

47 El hilo de la verdad, op. cit., p. 134.
} 
jeto 1 y Sujeto 2, pero esa forma de intersubjetividad no es capaz de neutralizar la escisión: el encuentro con uno mismo no puede sino ser acceso a una alteridad. ¿os es dado pensar un horizonte de experiencia en el que la mismidad lograse imponer su ley a esa resistente alteridad? Trías así lo cree. A la muerte compete confrontarnos con ese interrogante y, en tal medida, se constituye en elemento de prueba para la ética limítrofe. ${ }^{48}$ Que inevitablemente adquiere un sesgo metafísico-religioso, de orientación escatológica, pues lo mentado es un acontecimiento en el que el sujeto humano, el fronterizo que somos, experimentaría una plenificación o consumación de su ser mediante la identificación con su sosia celeste, «su doble ideal y su espejo no empañado». ${ }^{49}$ Tal es el núcleo esencial de lo que Trías describe, indistintamente, como consumación de la modulación religiosa de la tercera categoría (encuentro o cita entre Presencia y testigo), ${ }^{50}$ coincidencia entre uno mismo y el propio daimon, ${ }^{51}$ encaje sim-bólico del sujeto con la parte de sí replegada en el cerco hermético, ${ }^{52} \mathrm{o}$ "comunidad fronteriza (ontológica y topológica) entre los vivos y los muertos». ${ }^{53}$ Puede que ningún nombre se le adapte mejor que el de acontecimiento

48 «La muerte, al revelar la nada, es la gran prueba de la ética fronteriza» (La razón fronteriza, op. cit., p. 150). De hecho, la vocación metafísica de Trías se confirma en la decisión de encuadrar el fenómeno ético en un doble marco metafísico, recreador en clave antropológico-religiosa de la categoría de límite (este comparecería tanto en el nacimiento de la ética, con la llamada proveniente del cerco hermético, cuanto en su consumación escatológica): «Nuestra existencia está marcada por un doble tránsito: el que nos conduce, a través del complejo proceso de humanización, de la Naturaleza (sin inteligencia ni palabra) al Mundo (poblado de significación y sentido); y el que nos aboca, con la muerte, hacia el arcano en el cual halla el mundo su irrevocable confín. (...) Nuestra existencia se halla, pues, marcada y de-signada por ese Límite que la determina y define» (Ética y condición humana, op. cit., p. 34).

49 La razón fronteriza, op. cit., p. 152.

50 «En el espacio-luz del instante-eternidad la presencia revelada de lo sagrado y el testigo alcanzan un posible encuentro. Se adecuan uno al otro de modo que instituyen entre sí una genuina ecuación. Eso significa que reconocen su identidad de naturaleza y condición. Llegan a saber que uno y otro brotan de ese ser que siempre se les adelanta. Tal ser es, de hecho y de derecho, el limes" (La edad del espíritu, Barcelona, Destino, 1994, p. 348). Deificación que es, por ende, plenitud del ascenso ético al límite: «La hierofanía se hace conmensurable al fin con el testigo que la acoge. Este se reconoce congénere, idéntico en rango y en ser, en relación a aquello que se le revela. El testigo reconoce su ascenso hasta el último límite del mundo y su investidura de la condición fronteriza" (ibid.).

51 Probablemente sea en el ensayo «El acontecimiento ético» (Pensar la religión, Barcelona, Destino, 1997, pp. 227-255) donde Trías haya ido más lejos en la propuesta de esa daimonología o angelología, sobre la que sin duda pesa mucho cierta espiritualidad islámica. Se llega a hacer del daimon propio sustrato primordial del ethos de un sujeto cuya vocación es identificarse con aquel: «La ética deriva de la orientación que ese polo (angélico, daimónico) especifica en relación a la conducta o a las actitudes y al comportamiento del sujeto. Pero todo ello solo es posible si tiene lugar el acontecimiento que facilita ese encuentro o confrontación» (ibid., p. 230).

52 «El sujeto se halla, por consiguiente, desdoblado. O mejor, se halla partido, como una moneda o una medalla, una de cuyas partes constituye la principal pertenencia del sujeto (su signo de identidad), mientras que la otra parte ha quedado como propiedad y pertenencia de ese alter ego que es el daimon" (Pensar la religión, op. cit., p. 232). «En este sentido el encuentro del sujeto con su daímon debe determinarse como un acontecimiento simbólico, un encaje entre esas dos partes del sujeto (él mismo y su daimon propio)» (ibid., p. 233).

53 El hilo de la verdad, op. cit., p. 103. La comunidad tanática anticipa, en ese sentido, el futuro trans-mundano del fronterizo: «Esos muertos no son, de todos modos, "otros muertos"; o no lo son de modo preferente. Esos muertos en cierto modo, en el modo de la anticipación, ya lo somos. El cerco hermético no es algo ajeno a nos- 
espiritual, siempre y cuando coincidamos con Trías en entender por espiritu el telos o eskhaton de la vida fronteriza, el fin absoluto del existir humano. En ese misterio de un futuro anticipable en la experiencia limítrofe pero solo accesible tras la muerte culmina, en acorde escatológico, el acontecimiento ético.

\section{El judaísmo y la ética de Trías}

ACASO LA CONTRIBUCión MAYOR del pensamiento del límite al debate filosófico contemporáneo haya consistido en reactivar un campo de experiencia que o bien había caído en el desinterés o bien solo era objeto de atención crítico-negativa. Nos referimos a la religión. Ese gesto intelectual, sumado al de otros pioneros, marcó un punto de inflexión en la reflexión de las tres últimas décadas, cada vez menos proclive a dejar tan complejo asunto en las solas manos de un discurso unilateralmente ilustrado sobre la religio como superstición. Tras tomar conciencia de la vastedad y sobredeterminación del fenómeno, ningún filosofar responsable parece hoy dispuesto a satisfacerse con las cómodas recetas suministradas por el positivismo o la crítica de las ideologías. Sin por ello, naturalmente, restaurar obsoletos paradigmas de signo confesional (al menos en el caso de Trías; poco tiene que ver su incitadora propuesta con un neo-confesionalismo), se impone a la comunidad filosófica la exigencia de tomarse en serio el hecho religioso. Tanto en su producción filosófico-religiosa, presidida por el opus magnum de La edad del espiritu, como en sus restantes libros (donde el simbolismo religioso, una de las dos caras - la otra sería la artística— del universo simbólico, juega siempre un papel de primer orden), Trías ha hecho de la religión foco determinante de su pensamiento.

No en vano el religioso es, así lo hemos constatado, uno de los cuatro barrios de la ciudad fronteriza. Se le reconoce, pues, entidad y consistencia. Pero, además, su territorio no sufre una clausura topológica, sino que irradia hacia otros distritos ciudadanos, señaladamente el estético. Y también el ético. De nuestra presentación de la ética limítrofe se sigue que, aun no tratándose de una ética teológica sensu stricto, sí abundan en ella referencias esenciales a la experiencia religiosa. Sobre todo en dos momentos - los de su apertura y cierre- del fenómeno moral. El Sujeto 1 , condición de posibilidad del constituirse ético de la subjetividad, habla desde el

otros. Es algo que está ya, adelantado y anticipado, en nosotros, formando parte de nuestra propia experiencia. El muerto está en nosotros mismos. El cadáver que somos nos pertenece. (...) Constituye ese último futuro de nosotros mismos que forma acaso el humus de nuestra re-suscitación; o de la recreación de nosotros mismos, según el modelo de todas las metamorfosis que constituye el Ave Fénix, quizás de un modo que es imposible imaginar o pensar» (ibid., p. 103). 
misterio del cerco hermético y, por más que la cautela de Trías imponga respecto a él formas discursivas más alusivas que resueltamente tematizadoras (proceder refrendado por su propia elaboración de la noción clave de símbolo), no resulta fácil negar que el referente de la expresión "cerco hermético» coincide con aquello de lo que, desde otras coordenadas discursivas, dice ocuparse la teología. Por otro lado, reproduciendo un itinerario que sin duda evoca — y homenajea - el de la segunda crítica kantiana, la reflexión filosófico-moral culmina en la postulación, de signo escatológico, de una experiencia de plenitud espiritual, consistente en el encuentro entre el fronterizo (en términos filosófico-religiosos, el testigo) y la presencia que ante él comparece. Seamos aún más explícitos: todo el campo ético, cuyo núcleo experiencial recoge la tercera categoría (alzado del sujeto humano, en tanto que receptor de la orden proveniente del cerco hermético, al espacio limítrofe, donde adquiere la condición de fronterizo), será lo que, en clave filosófico-religiosa, exprese la teofanía o revelación de la presencia (hermética) ante el testigo (fronterizo). El estricto paralelismo entre acontecimiento ético y revelación religiosa no debiera sorprender, por lo demás, en un pensador para quien idea (filosófica) y símbolo (artístico y/o religioso) no son sino sendas expresiones de una unidad de orden superior, el arquetipo.

Queda por determinar si entre ambos elementos —ético y religioso- cabe establecer también un vínculo genético. Una lectura de la filosofía práctica de Kant en términos de "teísmo moral» abonaría la prioridad de lo ético como puerta de acceso al ámbito religioso (inmortalidad del alma y existencia de Dios son dos "postulados de la razón práctica»). No negamos que el pensamiento ético de Trías invite a transitar ese camino, sobre todo en su coronación escatológica, pero cabe también efectuar el trayecto inverso, o sea, interpretar su tematización del fenómeno moral como trasunto filosófico de una experiencia religiosa, por más que esta actuase con sordina, a manera de inspiración velada o implícita del discurso explícito. Tal es nuestra hipótesis, formulada aquí como tal y por ende abierta a un posible debate crítico en el marco de la recepción del pensamiento limítrofe: a la tematización de lo ético a cargo de Trías subyacería, aun sin asomar a la superficie discursiva, cierta forma de religión, nucleada en torno a significaciones afines a la propuesta categorial del filósofo. Nos referimos a la experiencia del Israel bíblico y su prolongación en la tradición rabínica; con otras palabras, al judaismo. De resultar tal enfoque plausible (su momento interpretativo es, a todas luces, irreductible, pues sugiere deducir de la afinidad —entre un discurso filosófico y una tradición religiosa - un nexo de fundamentación o, al menos, una fuente de inspiración), contribuiría a confirmar, en un ámbito inesperado, una idea que consideramos capital para dar cuenta de la aventura de Occidente: su genealogía — no excluyente pero sí determinantemente— judía, habiendo de 
compartir Jerusalén con Atenas (y acaso Roma) la responsabilidad y el honor fundacionales del hecho civilizatorio europeo. Algo quizá no tan ajeno al temple espiritual de quien afirma de sí mismo: «soy y me reconozco hijo de Platón y de la Biblia». ${ }^{54} \mathrm{O}$ de quien no vacila en ejemplificar su propuesta ética con elementos extraídos del arsenal bíblico:

Puede alegorizarse y personificarse ese sujeto ausente como Divinidad y a su palabra como voz de Dios que ordena y manda a un sujeto cualquiera, el profeta Jonás por ejemplo, a cumplir y ejecutar cierto cometido, cierta empresa. ${ }^{55}$

¿Es la cita anterior un recurso meramente accidental, por entero exento de fuerza probatoria, o puede considerarse indicio de un estrato fundante, aunque de manera tácita, de la ética limítrofe? De la estricta literalidad del corpus de Trías — La edad del espiritu en particular - provienen incitaciones a poner a prueba la segunda posibilidad. En la gran obra sobre filosofía de la religión el repertorio categorial de siete unidades, que en los textos ontológicos comparece en forma sincrónica (sistema de las categorías), reviste, ante todo, significación diacrónica (filosofía de la historia en clave espiritual). Permite, en efecto, definir otros tantos eones que jalonan la evolución histórico-religiosa de la humanidad. ${ }^{56} \mathrm{Si}$ en los desarrollos filosófico-prácticos la tercera categoría era la llamada a fundar el factum de la moralidad, la reflexión histórico-religiosa recurre a aquella como instancia definitoria de un eón, el tercero, en la trayectoria espiritual del homo sapiens. ${ }^{57} \mathrm{Su}$ acontecimiento central consiste en el encuentro de la divinidad que, sin por ello exiliarse de su patria trascendente (cerco hermético), se revela y un sujeto elevado en razón de ello a la condición de testigo de la teofanía:

Lo sagrado, en esta tercera categoría, se presenta como aparición. Aparición relativa a alguien ante el cual hace acto de presencia. Se le llamará el testigo de la aparición. (...)

Tal testigo sale a su vez de su anonimato. Deja de ser un personaje humilde (hijo del humus o de la tierra) y se eleva al rango de figura capaz de detectar, reconocer y atestiguar la revelación de lo sagrado. (...)

\footnotetext{
${ }_{54}$ El hilo de la verdad, op. cit., p. 264. Cabría argüir, es cierto, que el filósofo catalán ha prestado desigual atención a ambos progenitores. Pero, ¿̇no es justamente ese el destino multisecular de Occidente? Lo esencial del legado judío no residiría tanto en la visibilidad (nuestra tradición reservó ese papel al ancestro heleno) cuanto en su persistencia y fecundidad a pesar del omnipresente hostigamiento (del olvido, la mutilación o el menosprecio al exterminio genocida) del que una y otra vez ha sido víctima.

55 Los limites del mundo, op. cit., p. 54.

56 Por lo demás, esa propuesta filosófico-histórica se desdobla en dos grandes ciclos. El primero de ellos, simbólico, (correspondiente a los dos primeros libros de La edad del espíritu) recapitularía la historia religiosa pre-moderna; el segundo, espiritual, (tercer libro) ofrece una relectura de la cultura moderna en perspectiva espiritual. Aquí recurriremos al primero de los ciclos.

57 Cf. La edad del espiritu, op. cit., pp. 121-156 ("Tercera categoría: El encuentro entre la presencia y el testigo»).
} 
Es, pues, el encuentro [entre presencia y testigo], como tal encuentro, lo que esta categoría acierta a revelar. ${ }^{58}$

Caracteriza al tercer eón — cuyas cuatro áreas culturales son la India védica, Irán, Grecia y el judaísmo - la prioridad de la palabra en el acontecimiento teofánico, es decir, la textura irreductiblemente verbal de la revelación:

Esa comunicación [entre figura teofánica y testigo] promociona a primer plano de la atención categorial la palabra (lógos, en griego; Wāch o Brahma, en sánscrito) a través de la cual ese encuentro alcanza su plena consumación. Esa palabra, palabra del Dios, o palabra del Ser, que el oído atento del testigo acoge y revela, o hace manifiesta a su comunidad testimonial, acaba siendo recogida en una escritura santa, o libro santo y sagrado, en el cual dicha palabra es testimoniada. ${ }^{59}$

La índole verbal de la revelación unifica el acontecer histórico-religioso del tercero de los eones, pero esa unidad se muestra atravesada por una dualidad constitutiva. Si bien es cierto que la palabra es el núcleo fundante de esta etapa religiosa, no lo es menos que admite dos regímenes: por un lado, la enunciación que proclama la verdad del Ser; por otro, el mandato que expresa la voluntad de Dios. Al primero corresponde el área poético-filosófica (India y Grecia), afecta a concebir la Unidad como principio impersonal (monismo trascendental) objeto de gnosis; al segundo, el área profético-sofiológica (Irán e Israel), que ve en la Unidad portadora de sabiduría una entidad personificada (monoteísmo) que reclama de la voluntad del testigo una recta elección. ${ }^{60}$ ¿Cómo no reconocer en esa duplicidad la inspiración histórico-religiosa de la distinción filosófica entre dos flexiones del lógos, la enunciativa o constatativa y la prescriptiva o moral? ¿Cómo, entonces, no conectar el discurso ético de la filosofía limítrofe con su teorización de la experiencia religiosa judía (e irania, es cierto)? ¿No son ambos variaciones de lo mismo? Si el pensamiento de Trías insiste, kantianamente, en la heterogeneidad de ontología y ética, razón teórica y razón práctica, palabra apofántica y voz imperativa, al tiempo que reivindica lo religioso como matriz fundante del acontecer espiritual en que se despliega la aventura de lo humano, no parece factible mantener inconexas la meditación filosófico-religiosa sobre el judaísmo (como

58 La edad del espiritu, op. cit., pp. 121-123.

59 La edad del espiritu, op. cit., p. 153. En rigor, el registro en el Libro de la palabra revelada pertenece al cuarto eón, en continuidad con el que lo precede como transcripción escrita de la teofanía oral: «En este cuarto eón lo sagrado, a través del símbolo, se abre a la palabra y a la escritura; se rompe el cerco de silencio del ámbito de lo sagrado y estalla la voz atronadora (de Dios, del Ser)» (ibid., p. 174).

${ }^{60}$ "Este carácter imperativo de la palabra de Dios contrasta con el carácter enunciativo y declarativo de la palabra del sen» (La edad del espiritu, op. cit., p. 182). 
religión del área profético-sofiológica) y la tematización del fenómeno moral. Hacerlo sería tanto como traicionar la unidad insistentemente postulada de lo simbólico y lo categorial en el arquetipo (o Mónada). ${ }^{61}$

Así pues, el propio autor nos sitúa en la antesala de nuestra hipótesis interpretativa: su ética reitera, en un plano filosófico-práctico, el núcleo fundante de la experiencia religiosa de Israel, de suerte tal que cabría rastrear en la fenomenología del hecho moral los principales momentos de la aventura bíblica. Solo resta constatarlo, aunque sea esquemáticamente. En el barrio ético de la ciudad fronteriza, el suceso inaugural viene dado por una voz que, desde el cerco hermético, insta al sujeto humano a desprenderse de su hábitat físico alzándose al límite o frontera. Esa palabra imperativa de origen celeste es lo que también vertebra la teofanía de Israel. La divinidad bíblica es radicalmente trascendente y, en consecuencia, su manifestación no puede confundirse con ningún suceso físico o mundano; apenas con la sutileza, rayana en la inmaterialidad, de una orden susurrada. Así da cuenta el texto veterotestamentario de la presencia divina como ruah (espíritu):

Entonces, he aquí que Yahveh pasa y un viento recio y fuerte descuaja las montañas y quiebra peñas precediendo a Yahveh; mas Yahveh no está en el viento. Tras el viento, un terremoto; mas Yahveh no está en el terremoto. Tras el terremoto, fuego; mas Yahveh no está en el fuego; y tras el fuego, el silbo de un aura tenue. (1 Reyes 19,11-12)

Por otro lado, la invisibilidad de quien habla (el testigo bíblico escucha una voz cuyo emisor se sustrae a su mirada) coincide con el repliegue misterioso del Sujeto 1; ni siquiera el hecho de que el Dios confíe su nombre al testigo perturba el incógnito, dado que se trata de un nombre misterioso e impronunciable (tetragrámaton). $\mathrm{Al}$ igual que el habla del Sujeto 1 reviste forma imperativa, la palabra de YHWH es Torah (a la vez ley e instrucción). En ambos casos, el oyente se define como receptor de un mandamiento y se ve sumido, por tanto, en una situación inicialmente heterónoma (fides ex auditu).

Pero que supone para él un radical cambio de identidad: si únicamente en la audición cabe devenir fronterizo y asumir en consecuencia la carga de la culpa, el encuentro con la deidad redefine el estatuto del sujeto, simbolizado en el cambio de nombre (así, Jacob se convierte en Israel) de quien recibe el requerimiento

61 «La Mónada es, de hecho, el arquetipo en el cual se halla sintetizada su expresión simbólica y la Idea (y el Ideal correspondiente) que revela su significación y su sentido. Como tal arquetipo es la Mónada una síntesis de símbolo e idea. O es el gozne o la bisagra que articula, en forma copulativa y conjuntiva, el símbolo con la idea» (La edad del espiritu, op. cit., p. 687). 
divino y con él la conciencia de pecado. (Incluso el alzado ético del humano al cerco fronterizo tiene su precedente en la escenografía montañosa - Sinaí como paradigma - de la revelación judía). Pero quizá ningún elemento resulte más significativo que el recurso compartido a un paradójico nexo entre heteronomía inicial y autonomía posterior: sujeto bíblico y fronterizo experimentan su libertad en tanto que prolongación de la orden escuchada, en virtud de la alternativa fidelidad/infidelidad a la Alianza (berit) en el primer caso y a resultas de la interrupción, o incompletud, del imperativo en el segundo. Lo común es la concepción de la libertad como respuesta a una orden trascendente. Respuesta que, en la ética limítrofe, materializa el Sujeto 3 al concretar la exigencia vacía en normas concretas y ejecutarlas en el cerco del aparecer, mientras que a Israel se le encomienda la tarea de redimir un mundo injusto, lo que ahonda el contraste entre los polos normativo y fáctico de la acción moral. Por otra parte, la constante tensión entre cumplimiento de la Ley y deriva idolátrica tendría su trasunto ético en la contraposición del imperativo pindárico y sus dos posibles transgresiones (invasión del cerco hermético o retorno a la matriz).

Sin embargo, podría alegarse, ¿no es la postulada deificación de la subjetividad fronteriza (en forma de encaje o ajuste entre el sujeto mundano y su doble celeste) incompatible con la innegociable trascendencia de una divinidad que rehúye toda compromiso antropomórfico? Si bien la cuestión es difícil, cabe al menos recordar dos factores esenciales del espíritu judío. Uno remite al origen: en la creación de Adán, el artífice se propone hacerlo «a su imagen y semejanza». El otro, aún más esencial (por cuanto polariza la vivencia religiosa hacia un horizonte escatológico cuya emulación fronteriza sería la idea de un acontecimiento espiritual), ${ }^{62}$ se encamina hacia un horizonte de futuro, el del cumplimiento mesiánico, del que se espera la definitiva conciliación entre YHWH y la humanidad objeto de su elección, siendo de hecho el personaje del Mesías una figura ambivalente, en la que parecen confundirse (al menos, acercarse al máximo) lo divino y lo humano. Por lo demás, el judaísmo tardío incorporó al núcleo de la fe monoteísta la creencia en la inmortalidad personal y, por ende, en una existencia transmundana de plenitud en la morada celeste, por más que ese elemento jamás llegase a anular la prioridad de la acción histórica a cargo de Israel como agente colectivo de la Redención.

\footnotetext{
${ }^{62}$ ¿Es posible pensar la referencia de Trías al eskhaton del espíritu fuera de la axiomática monoteísta y su primacía del futuro (promesa de un mundo definitivamente redimido) sobre la nostalgia de una edad áurea trágicamente perdida en el origen? (No cabe equiparar, en el imaginario judío, la potencia del ideal mesiánico, y su registro emocional en la esperanza, a una problemática nostalgia del Edén perdido. Incluso si el porvenir escatológico puede presentarse como restauración del existir paradisíaco, sigue en pie el hecho de que la aproximación a él es marcha hacia delante y no retorno a un pasado primordial).
} 


\section{La inhumanidad del hombre}

«Decir que entonces nos Sentíamos impugnados como hombres, como miembros de la especie, puede parecer un sentimiento retrospectivo, una explicación posterior. Sin embargo, eso es lo que vivimos de forma más inmediata y percibimos constantemente. Y, por otra parte, eso es exactamente lo que desearon los otros. El hecho de cuestionarse la cualidad de hombre provoca una reivindicación casi biológica de la pertenencia a la especie humana. Más tarde sirve para meditar sobre los límites de esta especie, sobre su distancia de la "naturaleza" y su relación con ella, por tanto sobre cierta soledad de la especie y, en fin, sirve sobre todo para concebir una visión clara de su unidad indivisible. ${ }^{63}$ Extraídas del prólogo de $L a$ especie humana —único libro escrito por Robert Antelme, superviviente del sistema concentracionario nazi, y una de las obras imperecederas del siglo XX-, estas palabras nos sitúan ante lo que probablemente sea el desafío máximo que nuestra reciente experiencia colectiva propone al pensamiento: hemos de hacernos cargo de una situación histórica en la que se perpetró, en el corazón de Europa, una radical inhumanidad, aunque no en virtud de la irrupción de un enemigo no-humano sino como efecto de la propia acción de los hombres. Ahí reside el escándalo: a contrapelo de la axiomática del humanismo clásico, lo inhumano ya no designa una región óntica ajena al homo sapiens, sino que se inscribe en la textura de su ser. La meditación de Antelme es, sin duda, afirmativa (el intento de expulsar a un grupo de humanos de la especie — tal fue el designio materializado en el Lager — no puede sino saldarse con un fracaso, pues incluso en la degradación extrema del vínculo entre deportados y SS se instituye una forma, por perversa que sea, de intersubjetividad, confirmándose la pertenencia de víctima y verdugo a una sola especie), ${ }^{64}$ pero la suya es una afirmación trágica, pues confirma la unidad de la especie al precio de asumir que le pertenece como posibilidad esencial hacer efectiva (lo inhumano, que comenzó siendo delirio ideológico, acabó cobrando plena realidad) una situación en la que uno de sus miembros puede tratar al otro como no-humano y, más aún, convertirlo en tal (eso es lo que la figura del musulmán, forma extrema

\footnotetext{
${ }_{63}$ R. Antelme, La especie humana, trad. de T. Richelet, Madrid, Arena Libros, 2001, p. 11.

64 «(...) si, entre los SS y nosotros — es decir, en el momento de supremo distanciamiento entre los seres, en el momento en que el límite de la esclavitud de los unos y el límite del poder de los otros parecen deber detenerse en un nexo sobrenatural- , no podemos percibir ninguna diferencia sustancial respecto a la naturaleza y frente a la muerte, nos vemos obligados a decir que solo hay una especie humana. Que todo lo que enmascara esta unidad en el mundo, todo lo que conduce a los seres a una situación de explotación, de esclavitud, lo que implicaría de por sí la existencia de la variedad de las especies, es una falsedad y una locura; y que nosotros tenemos aquí la prueba de ello, y la prueba más irrefutable, ya que la peor de las víctimas no puede sino constatar que, en su peor acción, el poder del verdugo tan solo puede ser un poder más del hombre: el poder de matar. Él puede matar a un hombre, pero no puede transformarlo en algo distinto" (R. Antelme, op. cit., p. 226).
} 
de negación de la subjetividad en los campos nazis, encarna). De ahí que el desafío aludido se imponga, ante todo, como vértigo: la acumulación de barbarie en la pasada centuria impone a la filosofía la tarea de repensar, desde lo inédito de una experiencia máximamente perturbadora, la humana conditio en su abisal verdad, la de una condición ontológica que incluye, sin remedio, la posibilidad de su propia negación. He ahí la tarea, inextricablemente antropológica y ético-política, que una filosofía exigente consigo misma ha de acometer. Aunque hasta ahora lo haya hecho en muy escasa medida.

¿Cabe encontrar en la ética del límite, y la política que la prolonga, algún elemento que contribuya a arrojar luz sobre la desolación consumada? Hemos de constatar, en primer término que el corpus de Trías no incorpora una reflexión sobre lo acontecido en el universo concentracionario, o apenas lo hace de forma alusiva e indirecta. ${ }^{65}$ Pero no es menos cierto que su propuesta ético-política presta atención sostenida al pavoroso despliegue de barbarie en la historia del siglo XX, a sus premisas antropológicas y a sus consecuencias cívicas.

En primer término, ofrece Trías una meditación sobre el mal arraigada en la experiencia de la libertad, «nuestro mejor don, y también el más peligroso de los regalos». ${ }^{66} \mathrm{La}$ libertad es, en efecto, determinación antropológica fundamental y sobre ella reposa la posibilidad, para el sujeto humano, de ser fronterizo, en respuesta positiva al imperativo pindárico. Pero asumir la libertad implica correr el riesgo de contradecir, en palabras y acciones, esa condición fronteriza o humana conditio, de suerte tal que en lugar de dar cumplimiento a lo humano se consume lo inhumano: «Solo un ser capaz de hacer el mal, o de generar desorden, caos y entropía en razón de su propensión hacia lo que le contra-dice (lo inhumano), solo un ser de ese carácter es verdadera y realmente libre.» ${ }^{67}$ Por reconocer lo inhumano como posibilidad fundamental de una subjetividad libre, Trías da acogida en su filosofía práctica a la lección de la barbarie contemporánea. Somos libres y, en consecuencia, nos es dado optar entre el bien y el mal, entre la plena efectuación de nuestra humanidad o la perpetración, siniestra y brutal, de lo inhumano. No cabe retener la libertad de la voluntad sin a la vez hacerse cargo de esa funesta posibilidad. De ese modo, la ontología trágica de los tres cercos confluye con la tragedia de la libertad:

\footnotetext{
65 Ante todo, en las elogiosas referencias al planteamiento de Hannah Arendt en Los orígenes del totalitarismo, obra que califica de «impresionante investigación sobre el poder político en la primera mitad del siglo XX" ( $L a$ política y su sombra, Barcelona, Anagrama, 2005, p. 137). En ese libro (cf. pp. 137-146) glosa Trías, desde sus propios supuestos filosófico-políticos, las líneas maestras de la analítica arendtiana del fenómeno totalitario. El texto de la Arendt mereció ya a finales de los ochenta una singular atención, subrayando Trías el proyecto de «hacer posible lo imposible» como centro del designio totalitario (cf. La aventura filosófica, op. cit., pp. 152 y ss.).

${ }^{66}$ La politica y su sombra, op. cit., p. 13.

${ }^{67}$ Ética y condición humana, op. cit., p. 99.
} 
bondad es ubicación del sujeto humano en su verdadera patria, el límite; la maldad, por el contrario, emerge allí donde la infidelidad a la vocación fronteriza absolutiza, como único ámbito de referencia existencial, uno de los otros dos cercos, en exceso inmanentista o trascendentalista. ${ }^{68}$

Si se trata de pensar la bondad en clave cívico-política, ha de diseñarse una conjunción equilibrada entre el imperativo de libertad y el de justicia, pues solo de «su precaria y siempre inestable síntesis» cabe esperar «la realización de la humanidad de lo humano» ${ }^{69}$ De no lograrse esa difícil síntesis, irrumpe, inexorable, la sombra de lo inhumano.

Su despliegue en la pasada centuria habría admitido dos formas principales, correspondientes a las dos mitades del siglo. Por un lado, el fenómeno totalitario que asoló la Europa de entreguerras celebrando un despotismo empeńado en negar el límite para acceder a su más allá hermético o su aquende matricial. ${ }^{70}$ En su furor ideológico, ese doble exceso pasional (amor-pasión y libido dominandi) instituyó un «absoluto negativo que señala un límite más allá del cual no hay humanidad posible (ni, por tanto, espacio para el poder y la política)», ${ }^{71}$ pues solo sabe afrontar lo humano como violencia exterminadora conducente «al escenario del Armagedón, o a una "batalla definitiva", o a una "decisión final", respecto a un hostis». ${ }^{72}$

Pero la segunda mitad del siglo XX no supo poner fin, a pesar de la derrota del totalitarismo nazi, al desencadenamiento del mal en forma de barbarie social y política. Lo prolongó, muy al contrario, en dos sombras de lo humano (la de la voracidad de un capital que, legitimándose en la idea de libertad, vuelve irrisoria cualquier demanda de justicia y la de un monstruo estatal que, en nombre de la igualdad, anula la libertad, y con ella la propia condición fronteriza), ${ }^{73}$ de cuya

${ }_{68}$ «El mal se produce si se reduce $a$ nada o bien el cerco hermético o bien el cerco del aparecer» (La aventura filosófica, op. cit., p. 86).

${ }_{69}$ Los limites del mundo, op. cit., p. 179. «Solo una comunidad impregnada y fecundada por esa doble ley (...) puede llamarse comunidad o patria humana: solo esa comunidad logra situarse propiamente en el lugar humano, en la frontera» (ibid., p. 179). La política y su sombra propondrá cuatro grandes principios ético-políticos (libertad, felicidad, justicia y seguridad), si bien insiste en las amenazas inherentes al último de ellos, sobre todo en un escenario geopolítico dominado por el miedo.

${ }^{70}$ «El déspota es doblemente usurpador: ocupa el lugar vacío del sujeto metafísico, al que tiende a "doblar" con la figura de un ser divino con quien actúa y comunica; pero asimismo pretende investir el lugar único y exclusivo de la madre originaria, formando indisoluble unidad con el ancestro que le dio el ser, al que entonces entronizará también como "doble" con el que se halla en comunicación. Esa "madre trascendente" a la que dice servir y defender en exclusivo monopolio le aparece como "madre patria”" (Los limites del mundo, op. cit., pp. 135-136).

${ }^{71}$ La politica y su sombra, op. cit., p. 145.

${ }_{72}$ La politica y su sombra, op. cit., pp. 142-143.

${ }^{73}$ En los siguientes términos describe Trías el escenario de la guerra fría como confrontación entre potencias hostiles pero que comparten la incapacidad de arbitrar una síntesis de libertad y justicia: «Terra y Antiterra son los amos de nuestro mundo moderno en crisis: y lo son en razón de sus desmedidos territorios sin fronteras, los más aptos para que se realice la fuerza despobladora y desertizadora del "poder de la riqueza" (en Terra, patria del dólar) y del "poder del Estado" (en Antiterra, la patria del Trabajador)» (Los límites del mundo, op. cit., p. 187). 
hostilidad nace nuestro mundo de posguerra, presidido por la más siniestra de las amenazas, la de la destrucción nuclear de la especie como apoteosis de lo inhumano:

La filosofía de la posguerra es, por esto, esencialmente trágica: no puede ya dejar de convivir con ese horizonte final de aniquilación. (...) La aniquilación de lo humano es nuestro horizonte. ${ }^{74}$

Nada garantiza, en términos de salud cívica o sensatez política, esa pavorosa constatación. La lucidez no tiene, es verdad, por qué aportar consuelo. Pero no es menos cierto que la conciencia de la posibilidad del mal es requisito imprescindible para atajarlo. No habrá sido la menor contribución de la filosofía limítrofe (y, muy en particular, de su exploración del barrio ético-político) mantenernos alerta ante esa incómoda verdad:

Pues nada hay más humano que la conducta inhumana, de manera que deberíamos invertir el adagio latino y afirmar, si somos verdaderos con nosotros mismos: "nada inhumano nos es ajeno". Y es que lo inhumano es la alargada sombra que proyecta el propio cuerpo iluminado de nuestra subjetividad. ${ }^{75}$

${ }^{74}$ Los límites del mundo, op. cit., p. 192. Filosofía del futuro invitaba ya a pensar una política desde el más inhóspito de los horizontes: "Y bien, en el presente, en el hoy, ese "velo del ser", la nada, irisa el horizonte como presencia compacta desde la cual podemos, en tanto que seres humanos, determinarnos. Aparece bajo la forma siniestra y obscena de una nada posible, a la vista, a la mano, que nos habla de extinción biológica y exterminio de la especie, en el lenguaje y ademán del incontrolado y anárquico crecimiento industrial capitalista y en el gesto espeluznante del arma atómica. Vivimos alucinados por el más alucinante de los hongos, el hongo atómico» (Filosofía del futuro, Barcelona, Ariel, 1983, p. 9).

75 El hilo de la verdad, op. cit., p. 57. 


\section{Referencias Bibliográficas}

Antelme, Robert, La especie humana, trad. de T. Richelet, Madrid, Arena Libros, 2001.

Gombrich, E. H., «Las mitologías de Botticelli», en id., Imágenes simbólicas, trad. de R. Gómez Díaz, Madrid, Alianza Editorial, 1983, pp. 63-130.

Trías, Eugenio, Filosofía del futuro, Barcelona, Ariel, 1983.

- El artista y la ciudad, Barcelona, Anagrama, $1983^{2}$.

— Los límites del mundo, Barcelona, Ariel, 1985.

- La aventura filosófica, Madrid, Mondadori, 1988.

— Lo bello y lo siniestro, Barcelona, Ariel, 1988.

— Lógica del límite, Barcelona, Destino, 1991.

- La edad del espiritu, Barcelona, Destino, 1994.

- Diccionario del espiritu, Barcelona, Planeta, 1996.

- Pensar la religión, Barcelona, Destino, 1997.

- La razón fronteriza, Barcelona, Destino, 1999.

- Ética y condición humana, Barcelona, Península, 2000.

- Ciudad sobre ciudad, Barcelona, Destino, 2001.

- El hilo de la verdad, Barcelona, Destino, 2004.

- La politica y su sombra, Barcelona, Anagrama, 2005.

DOI: https://doi.org/10.15366/bp2019.22.001

Bajo Palabra. II Época. No 22. Pgs: 21-56 
